LBL-36511

UC-401

\title{
Hydrogen-Ion Titrations of Amino Acids and Proteins in Solutions Containing Concentrated Electrolyte
}

\author{
Florian Fergg, ${ }^{1}$ Daniel E. Kuehner, Harvey W. Blanch, and John M. Prausnitz*
}

Department of Chemical Engineering, University of California and

Chemical Sciences Division, Lawrence Berkeley Laboratory

University of California, Berkeley, California 94720

1Visiting Researcher, Technische Universität München, Lehrstuhle B für Verfahrenstechnik

*Author to whom correspondence should be addressed

December 1994

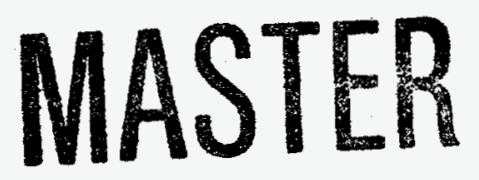

This work was supported by the Director, Office of Energy Research, Office of Basic Energy Sciences, Chemical Sciences Division, of the U.S. Department of Energy under Contract No. DE-AC03-76SF00098. 


\section{DISCLAIMER}

This report was prepared as an account of work sponsored by an agency of the United States Government. Neither the United States Government nor any agency thereof, nor any of their employees, make any warranty, express or implied, or assumes any legal liability or responsibility for the accuracy, completeness, or usefulness of any information, apparatus, product, or process disclosed, or represents that its use would not infringe privately owned rights. Reference herein to any specific commercial product, process, or service by trade name, trademark, manufacturer, or otherwise does not necessarily constitute or imply its endorsement, recommendation, or favoring by the United States Government or any agency thereof. The views and opinions of authors expressed herein do not necessarily state or reflect those of the United States Government or any agency thereof. 


\section{DISCLAIMER}

Portions of this document may be illegible in electronic image products. Images are produced from the best available original document. 


\section{Contents}

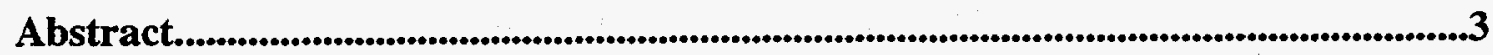

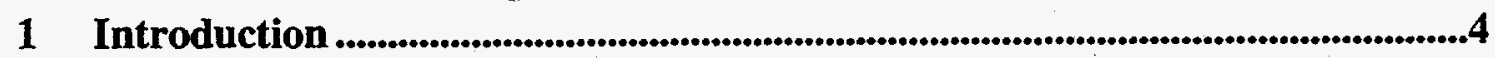

2 Theory ..............................................................................................................................66

3 Experimental Methods..............................................................................12

3.1 Titration Apparatus ...................................................................................12

3.2 Software Description .................................................................................15

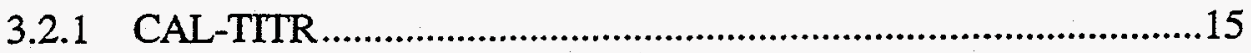

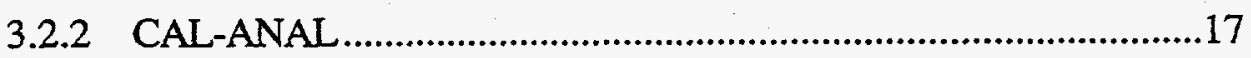

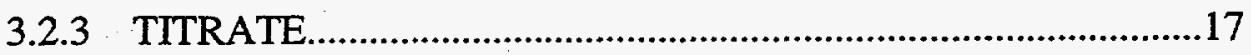

3.2.4 SETUPBTA

3.2.5 BETA90

3.3 Experimental Procedure .................................................................................19

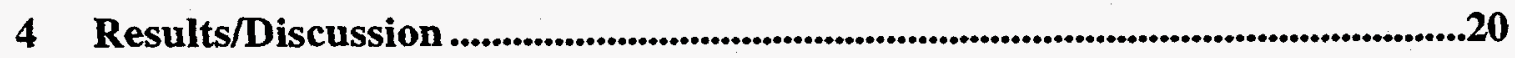

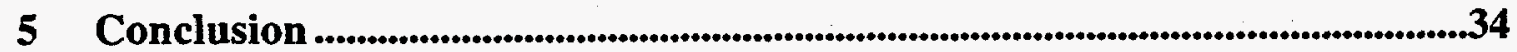

Appendix

A Amino-Acid Sequences of Lysozyme and a-Chymotrypsin...................................35

B Electrode Calibration .........................................................................................................37

C Details on Dosimat Pump Configuration and Operation .......................................39

D Lid Construction.............................................................................................................40

E Details of Apparatus Troubleshooting.......................................................................41

F Program Flow Sheet for CAL-TITR and TITRATE............................................42 
G Setup and Operation of BETA90

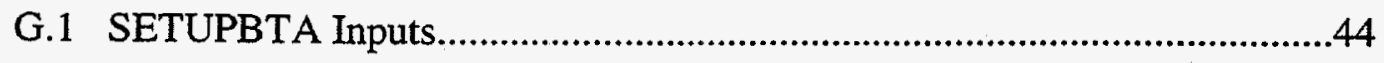

G.2 Refining Amino-Acid pKa's with BETA90 ...............................................45

H Experimental Procedure for Titration .....................................................................47

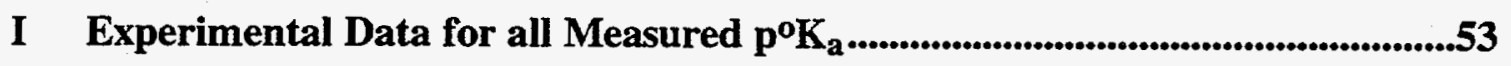

K Sample Titration-Data Recording.......................................................................56

Nomenclature ...................................................................................................................59

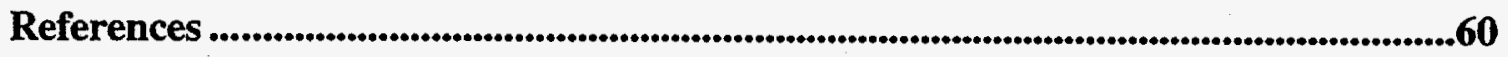




\section{Abstract}

This report describes a first attempt to quantify the net charge as a function of solution $\mathrm{pH}$ for lysozyme and $\alpha$-chymotrypsin at $0.1 \mathrm{M}, 1.0 \mathrm{M}$ and $3.0 \mathrm{M}$ ionic strength, (IS). The calculations are based on the residue (titratable group) $\mathrm{pK}_{\mathrm{a}}$ 's in the amino-acid sequence of the protein. To determine these $\mathrm{pK}_{\mathrm{a}}$ 's, a simple theory was used which assumes that the $\mathrm{pK}_{\mathrm{a}}$ 's are independent from each other in the protein and are equal to their $\mathrm{pK}_{\mathrm{a}}$ values in free amino-acid solution (Independent-Site Theory, IST).

Residue $\mathrm{pK}_{\mathrm{a}}$ 's were obtained from amino-acid hydrogen-ion titrations at three different $\mathrm{KCl}$ concentrations corresponding to $0.1 \mathrm{M}, 1.0 \mathrm{M}$ and $3.0 \mathrm{M}$ ionic strength. After construction of a suitable apparatus, the experimental procedure and data reduction were computerized to perform a large number of titrations. Most measured $\mathrm{pK}_{\mathrm{a}}$ 's showed high reproducibility (the difference of $\mathrm{pK}_{\mathrm{a}}$ values observed between two experiments was less than 0.05 ). For $I S=0.1 \mathrm{M}$, observed $\mathrm{pK}_{\mathrm{a}}$ 's agreed with literature values to within a few hundredths of a $\mathrm{pH}$ unit. Furthermore, the ionic-strength dependence of the $\mathrm{pK}_{\mathrm{a}}$ 's followed the trends reported in the literature, viz. $\mathrm{pK}_{\mathrm{a}}$ values decrease with increasing ionic strength until they reach a minimum at about IS $=0.5 \mathrm{M}$. At still higher IS, $\mathrm{pK}_{\mathrm{a}}{ }^{\prime} \mathrm{s}$ increase as the ionic strength rises to $3 \mathrm{M}$.

The known $\mathrm{pK}_{\mathrm{a}}$ 's of all titratable groups in a protein were used with the IST to give a first approximation of how the protein net charge varies with $\mathrm{pH}$ at high ionic strength. A comparison of the titration curves based on the IST with experimental lysozyme and $\alpha$ chymotrypsin titration data indicates acceptable agreement at IS $=0.1 \mathrm{M}$. However, comparison of measured and calculated titration curves at IS $=1 \mathrm{M}$ and $\mathrm{IS}=3 \mathrm{M}$ indicates only qualitative agreement. 


\section{Introduction}

Protein precipitation is a convenient method for concentrating protein from dilute solutions. Salting-out, the precipitation of protein by high electrolyte concentration, is a commonly used technique. Experimental work and theoretical modeling are conducted to gain a quantitative understanding of the nature of protein interactions in concentrated salt solutions [1-3]. To support modeling efforts, it is important to quantify the dependence of protein net charge on solution $\mathrm{pH}$ at high salt ionic strength, e.g. 3M. The current literature provides charge/pH information for some proteins only at low ionic strengths, e.g. 0.01 $0.2 \mathrm{M}[4]$.

Hydrogen-ion titration experiments yield the relative net charge of a protein as a function of $\mathrm{pH}$. To determine absolute net charge, it is necessary to know one charge/pH point exactly. An experimental determination of the $\mathrm{pH}$ point at which the protein has zero net charge (the isoelectric point, $\mathrm{pI}$ ) can be made by isoelectric focusing (IEF). However, in high ionic-strength solutions, conventional IEF is not possible. It is necessary to have an independent method for measuring or calculating the $\mathrm{pI}$ at high salt concentrations.

In an attempt to calculate the pI's of chymotrypsin and lysozyme in high IS solutions, we used a simple theory for calculating the net charge as a function of $\mathrm{pH}$. We assume that the overall charge of the protein is equal to the sum of the charges of all the protonatable groups in amino-acid sequence of this protein. With knowledge of all the individual hydrogen ion dissociation equilibrium constants, the $\mathrm{K}_{\mathrm{a}}$ 's, of the protonatable sites in a protein, it is simple to calculate the absolute net charge of a protein as a function of $\mathrm{pH}$. Determination of individual amino-acid $\mathrm{K}_{\mathrm{a}}$ 's in proteins is difficult and is a topic of much research, especially for residues buried in the interior of proteins [5]. Our independent-site theory (IST) makes the (large) assumption that the $\mathrm{K}_{\mathrm{a}}$ 's of amino acids in the protein are equal to their $\mathrm{K}_{\mathrm{a}}$ 's in free solution. These are measurable in high ionic strength by performing hydrogen-ion titrations of amino acids in solutions containing concentrated electrolyte. The amino-acid sequence of the protein of interest determines which amino acids need to be titrated to find their $\mathrm{K}_{\mathrm{a}}$ 's for theoretical net-charge calculations.

In this work we present a detailed description of an apparatus that we constructed to perform high-precision hydrogen-ion titrations. We present and discuss the result of 
amino-acid titrations in solutions of $\mathrm{KCl}$ at $0.1 \mathrm{M}, 1.0 \mathrm{M}$ and $3.0 \mathrm{M}$ ionic strength. Also presented are preliminary results for titrations of lysozyme and $\alpha$-chymotrypsin in a few different solutions containing $\mathrm{KCl}$ at high ionic strength. A comparison is given for experimental and theoretical protein net-charge dependence on solution $\mathrm{pH}$. Results and applicability of the IST are discussed. 


\section{Theory}

Each protein molecule has in its amino-acid sequence many different residues with potential hydrogen-ion equilibria. At any given $\mathrm{pH}$, these residues will be in various protonation states, depending on their individual hydrogen-ion dissociation constant, or $\mathrm{pK}_{\mathrm{a}}$ 's. Thus the protein will have a net charge which varies with $\mathrm{pH}$. The dissociation of hydrogen ions will also be affected by the presence of added electrolyte, and therefore the net charge/pH behavior of a protein will be a function of solution ionic strength.

Protein hydrogen-ion titration experiments yield relative net charge as a function of $\mathrm{pH}$. To determine absolute net charge, it is required to know one charge/pH point exactly. In solution with low concentration of added electrolyte an experimental determination of the $\mathrm{pH}$ point (the protein has zero net charge) can be made by isoelectric focusing (IEF) [6]. However, in high ionic-strength solutions, conventional IEF is not possible. An independent method is necessary for either measuring or calculating the isoelectric point (pI) of the protein .

With knowledge of all the individual $\mathrm{pK}_{\mathrm{a}}$ 's of all the possible hydrogen-ion equilibria in a protein, it is possible to calculate the absolute net charge of a protein as a function of $\mathrm{pH}$. Experimental determination of the $\mathrm{pK}_{\mathrm{a}}$ 's of equilibria in the interior of proteins is difficult and is a topic of much research [5]. In an attempt to calculate the pI's of chymotrypsin and lysozyme in high ionic-strength solutions, we used an independent-site theory (IST). Our independent-site theory makes the (large) assumption that the $\mathrm{pK}_{\mathrm{a}}$ 's of amino acids in the protein are equal to their free-solution values, and that each titratable site is independent of all others.

\section{Independent-Site Theory}

In every protein molecule there are $\mathrm{n}_{\mathrm{i}}$ acid/base equilibria of type $i$, each described by a hydrogen-ion dissociation constant $\mathrm{K}_{\mathrm{ai}}$ such that, in dilute solutions where all activity coefficients are unity [7]:

$$
H A_{i} \stackrel{K_{a i}}{\longrightarrow} H^{+}+A_{i}^{-}
$$




$$
K_{a i}=\frac{\left[H^{+}\right] \cdot\left[A^{-}\right]_{i}}{[H A]_{i}} \cdot \frac{\gamma_{H^{+}} \cdot \gamma_{A_{i}^{-}}}{\gamma_{H A_{i}}}
$$

and

$$
K_{a i}^{o}=\frac{\left[H^{+}\right] \cdot\left[A^{-}\right]_{i}}{[H A]_{i}}=\frac{K_{a i}}{K_{\gamma}}
$$

The individual $\mathrm{n}_{\mathrm{i}}$ 's are known from the amino-acid sequence of a given protein. These equilibria occur on the side chains of acidic or basic residues and at the amino and carboxyl termini of the amino-acid chain in the protein. Taking the logarithm of equation (3) yields the well-known Henderson-Hasselbach equation [7]:

$$
p^{o} H-p^{o} K_{a i}=\log \frac{\left[A^{-}\right]_{i}}{[H A]_{i}}
$$

where

$$
\begin{aligned}
& p^{o} H=-\log \left[H^{+}\right] \\
& p^{o} K_{a i}=-\log K_{a i}^{o}
\end{aligned}
$$

A mass balance on titratable sites of type $i$ dictates that the total concentration of sites (in moles of sites per liter of protein solution) must equal the sum of the concentrations of unprotonated and protonated sites of type $i$ :

$$
[S]_{i}=\left[A^{-}\right]_{i}+[H A]_{i}
$$

Here $[\mathrm{S}]_{\mathrm{i}}=\mathrm{n}_{\mathrm{i}} \cdot[\mathrm{P}]$, where $[\mathrm{P}]$ is the total protein concentration, in moles/liter. Combining equations (4) and (7) yields expressions for the molar concentrations of protonated and unprotonated sites of type $i$ in terms of the quantities $\mathrm{pH}, \mathrm{pK}_{\mathrm{ai}}$, and $\mathrm{n}_{\mathrm{i}}$ :

$$
\left[A^{-}\right]_{i}=[S]_{i}-\left(\frac{\left[A^{-}\right]_{i}}{10^{\left(p^{o} H-p^{o} K_{a i}\right)}}\right)=\frac{[S]_{i} \cdot 10^{\left(p^{o} H-p^{o} K_{a i}\right)}}{\left(10^{\left(p^{o} H-p^{o} K_{a i}\right)}+1\right)}
$$

and

$$
[H A]_{i}=[S]_{i} \cdot\left(1-\frac{10^{\left(p^{o} H-p^{o} K_{a i}\right)}}{10^{\left(p^{o} H-p^{o} K_{a i}\right)}+1}\right)
$$


Note that species $\mathrm{A}_{\mathrm{i}}^{-}$is not necessarily negatively charged; it may be either negative or neutral, depending on the particular dissociation equilibrium. Therefore, we define a function $f(x)$, which accounts for the valence of each species, as:

$$
f(x)=\text { charge on species } x \text {. }
$$

For an acidic side chain, e.g. aspartic acid,

protonated: $\quad \mathrm{R}-\mathrm{CH}_{2}-\mathrm{COOH} \Rightarrow \mathrm{HA} \Rightarrow \mathrm{f}(\mathrm{HA})=0$

unprotonated: $\mathrm{R}-\mathrm{CH}_{2}-\mathrm{COO}^{-} \Rightarrow \mathrm{A}^{-} \Rightarrow \mathrm{f}\left(\mathrm{A}^{-}\right)=-1$;

and for a basic side chain, e.g. lysine,

protonated: $\quad \mathrm{R}-\left(\mathrm{CH}_{2}\right)_{4}-\mathrm{NH}_{3}{ }^{+} \Rightarrow \mathrm{HA} \Rightarrow \mathrm{f}(\mathrm{HA})=1$

unprotonated: $\mathrm{R}-\left(\mathrm{CH}_{2}\right)_{4}-\mathrm{NH}_{2} \Rightarrow \mathrm{A}^{-} \Rightarrow \mathrm{f}\left(\mathrm{A}^{-}\right)=0$.

Then the net charge on a single protein molecule is:

$$
z_{\text {net }}=\sum_{i} z_{i}=\frac{1}{[P]} \sum_{i}\left(f\left(A_{i}^{-}\right) \cdot\left[A^{-}\right]_{i}+f\left(H A_{i}\right) \cdot[H A]_{i}\right)
$$

or

$$
z_{\text {net }}=\sum_{i}\left[f\left(A_{i}^{-}\right) \cdot\left\{\frac{n_{i} 10^{\left(p^{\circ} H-p^{o} K_{a i}\right)}}{10^{\left(p^{\circ} H-p^{o} K_{a i}\right)}+1}\right\}+f\left(H A_{i}\right) \cdot n_{i} \cdot\left\{1-\frac{10^{\left(p^{o} H-p^{o} K_{a i}\right)}}{10^{\left(p^{o} H-p^{o} K_{a i}\right)}+1}\right\}\right]
$$

This expression allows us to calculate the net charge on a protein as a function of $\mathrm{pH}$ and $\left\{\mathrm{pK}_{\mathrm{ai}}, \mathrm{n}_{\mathrm{i}}\right\}$ within the abovementioned assumptions of this independent-site theory.

Of the 20 natural amino acids found in most proteins, there are seven which have side chains with hydrogen-ion equilibria [7], namely:

$\begin{array}{llll}\text { arginine } & \text { cysteine } & \text { histidine } & \text { tyrosine } \\ \text { aspartic acid } & \text { glutamic acid } & \text { lysine } & \end{array}$

All of these side-chain equilibria, except the cysteine sulfhydryl equilibrium, are found in lysozyme and $\alpha$-chymotrypsin. Also, the amino-acid sequences of lysozyme and 
$\alpha$-chymotrypsin (see Appendix A) give the identity of titratable carboxyl and amino end groups on all the protein chains. Note $\alpha$-chymotrypsin has three chains linked via cysteine disulfide bridges, and thus six titratable end groups, while lysozyme has only one unbroken chain and thus 2 titratable end groups. The relevant end-group equilibria are:

$\begin{array}{lll}\text { alanine (amino) } & \text { isoleucine (amino) } & \text { tyrosine (carboxyl) } \\ \text { asparagine (carboxyl) } & \text { leucine (carboxyl) } \\ \text { cysteine (amino) } & \text { lysine (amino) }\end{array}$

To calculate protein net charge as a function of $\mathrm{pH}$, it is necessary to measure the $\mathrm{pK}_{\mathrm{a}}$ 's of all the relevant equilibria mentioned above via amino-acid hydrogen-ion titration. These titrations must be carried out in amino-acid solutions with ionic strengths corresponding to those found in our theoretical model. Also, protein titrations must be performed at solution conditions identical to those for amino-acid titrations to compare experimental protein-charge vs. $\mathrm{pH}$ curves to curves calculated from amino-acid $\mathrm{pK}_{\mathrm{a}}$ 's via IST.

\section{Effect of Ionic Strength on Hydrogen-Ion Equilibria: Calibration Titration}

In solutions of high ionic strength, care must be exercised in interpretation of experimental $\mathrm{pH}$ data. The $\mathrm{pH}$ of a solution, is strictly defined as [8]:

$$
p H=-\log \left(a_{H^{+}}\right)
$$

Hydrogen-ion activity, $\mathrm{a}_{\mathrm{H}^{+}}$, is the quantity observed in a $\mathrm{pH}$ measurement [8]. In dilute solutions, it is commonly assumed that the activity of the hydrogen ion is equal to its concentration [9]. In concentrated salt solutions, however, the hydrogen-ion concentration and activity are not equal; they are related by the activity coefficient, $\gamma_{\mathrm{H}^{+}}$. Hence $\mathrm{pH}$ in concentrated salt solutions is:

$$
p H=-\log \left(a_{H^{+}}\right)=-\log \left(c_{H^{+}} \cdot \gamma_{H^{+}}\right)
$$

Recall from equation 5 that quantity $\mathrm{p}^{\mathrm{o}} \mathrm{H}$ is equal to the $\mathrm{pH}$ only in the infinite-dilution limit, when the concentration and activity of hydrogen ion are equal: 


$$
p^{o} H=-\log \left(c_{H^{+}}\right)
$$

In general, and particularly for hydrogen ions in a concentrated salt solution:

$$
p H=p^{o} H-\log \left(\gamma_{H^{+}}\right)
$$

All theoretical calculations outlined above require $\mathrm{c}_{\mathrm{H}^{+}}$to determine net charge on a protein as a function of $\mathrm{p}^{\circ} \mathrm{H}$. Thus, it is necessary to relate titration data, which are based on activity measurements, to hydrogen-ion concentrations. Rather than attempting to estimate $\gamma_{\mathrm{H}^{+}}$as a function of solution conditions, it is possible to account for ionic strength effects directly in each ligand titration experiment. This is done by first performing a separate $\mathrm{pH}$ electrode calibration titration with strong acid/strong base titrants of exactly known $\mathrm{CH}^{+}$and $\mathrm{cOH}^{-}$, respectively $[4,10]$. These titrants contain sufficient supporting electrolyte to set their ionic strength equal to the desired value for the subsequent ligand titration. This calibration titration spans a broad range of hydrogen-ion activities (corresponding to $2<\mathrm{p}^{\circ} \mathrm{H}<12$ ) and is usually performed by titrating acid with base (increasing $\mathrm{p}^{\mathrm{oH}}$ ). At each step in the titration, $\mathrm{CH}^{+}$is known from the acid and basic titrant concentrations and from the total volume and volume basic titrant added. Also known at each step is $\mathrm{a}_{\mathrm{H}^{+}}$from the electrode response, expressed in $\mathrm{mV}$. Data from a calibration titration will therefore consist of a set of $\left(\mathrm{C}_{\mathrm{H}^{+}}, \mathrm{a}_{\mathrm{H}^{+}}\right)$points.

The operating relation for a $\mathrm{pH}$ electrode is a modified form of the Nernst equation [11]:

$$
E=E_{0}{ }^{\prime}+\frac{2.303 \cdot R \cdot T}{F} \cdot \log \left(c_{H^{+}} \cdot \gamma_{H^{+}}\right)
$$

where $\mathrm{E}$ is the measured hydrogen-ion activity $(\mathrm{mV}), \mathrm{E}_{0}{ }^{\prime}$ is the electrode reference potential $(\mathrm{mV}), \mathrm{R}$ is the gas constant $(8.314 \mathrm{~J} / \mathrm{mol} \cdot \mathrm{K}), \mathrm{T}$ is the system temperature $(\mathrm{K})$, and $\mathrm{F}$ is the Faraday constant $(96.485 \mathrm{C} / \mathrm{mol})$. This is equivalent to:

$$
E=E_{0}{ }^{\prime}+S \cdot \log \left(c_{H^{+}} \cdot \gamma_{H^{+}}\right)
$$

where $S=2.303 \cdot R \cdot T / F$. 
Here it may be asserted that $\gamma_{\mathrm{H}^{+}}$is essentially a constant over the range of the calibration titration since the titrants both have the same concentrations of supporting electrolyte. However it is expected that $\gamma_{\mathrm{H}^{+}}$will be different in different ionic-strength calibration titrations, due to the effect of electrolyte concentration on aH+ [10]. Rearranging equation (17) allows us to relate hydrogen-ion activity $(\mathrm{E})$ to hydrogen-ion concentration:

$$
E=E_{0}+S \cdot \log \left(c_{H^{+}}\right)=E_{0}-S \cdot\left(p^{\circ} H\right)
$$

where $E_{0}=E_{0}{ }^{\prime}+S \cdot \log \left(\gamma_{H^{+}}\right)$and is constant over a given calibration titration. From equation (18) it is apparent that $\mathrm{E}_{0}$ and $\mathrm{S}$ must be known to convert measured hydrogen-ion activity $(E)$ into concentration ( $\left.\mathrm{p}^{\mathrm{o}} \mathrm{H}\right)$. A Marquardt least-squares algorithm was used to fit $E_{0}$ and $S$ from calibration titration data [10]; details of this procedure are in Appendix $B$.

This calibration-titration process is performed prior to each ligand titration. The regressed electrode parameters $E_{0}$ and $S$ are used to convert measured hydrogen-ion activities to concentrations in the ligand titrations, to support the theoretical net-charge calculations described above. 


\section{Experimental Methods}

In each titration experiment, several steps occur before the titration of the ligand of interest (in our case amino acid or protein). Figure 2a illustrates the order of a typical titration experiment. Step $(1)^{*}$ is a titration of stock solutions of $\mathrm{HCl}$ and $\mathrm{KOH}$ (our acidic and basic titrants in all experiments) against potassium hydrogen phthalate and phenolphthalein to determine their exact molar concentrations of $\mathrm{H}^{+}$and $\mathrm{OH}^{-}$, respectively. This is important information for step (2), a titration of $\mathrm{HCl}$ with $\mathrm{KOH}$ from $\mathrm{pH} 2-12$, for the purpose of performing a broad range calibration of the $\mathrm{pH}$ electrode. Since many hydrogen-ion equilibria in amino acids and proteins have extreme $\mathrm{pK}_{\mathrm{a}}$ 's (e.g. aspartic acid carboxyl $\mathrm{pK}_{\mathrm{a}} \sim 2$, and arginine $\varepsilon$-imino $\mathrm{pK}_{\mathrm{a}} \sim 12$ ), careful calibrations are vital to measure these $\mathrm{pK}_{\mathrm{a}}$ 's accurately. With a properly calibrated electrode, it is then possible to gather reliable titration data for amino acids and proteins over the same $\mathrm{pH}$ range as the calibration (step (3)). Steps (2) and (3) are automated with software described below.

Regression of amino-acid $\mathrm{p}^{\circ} \mathrm{K}_{\mathrm{a}}$ 's from experimental titration data is carried out by sophisticated software (program BETA90, described in $\$ 3.2 .5$ below) developed in the College of Chemistry at the University of California at Berkeley [10]. Once the relevant amino-acid $\mathrm{p}^{\circ} \mathrm{K}_{\mathrm{a}}$ 's have been determined at a certain solution ionic strength, it is possible to calculate via IST the $\mathrm{p}^{\circ} \mathrm{H}$ dependence of protein net charge at the same ionic strength. Comparison of calculated protein titration curves with experimental data is discussed in $\S 4$.

\subsection{Titration Apparatus}

The apparatus used to conduct the experiments is shown in Figure 1. Hydrogen-ion titrations were carried out in a 500-mL jacketed reaction vessel (5). Prepared solutions of ligand (either amino acid or protein) were loaded into the vessel and agitated by a magnetic stirrer. Small aliquots of titrant, either acid or base, were injected through a fritted line (6) by a Dosimat 665 (2) (Metrohm, Westbury, NY) precision pump (see Appendix C for details on pump configuration and operation). $\mathrm{pH}$ was measured by a Ross combination

\footnotetext{
* Step (1) need be performed only when new reservoir volumes $(\sim 1.5 \mathrm{~L})$ of titrant are prepared; a typical reservoir is sufficient for approximately 15 ligand titrations. Since the reservoirs are blanketed with argon at a small positive pressure, carbon dioxide dissolution into the titrant is considered to be negligible.
} 
semimicro electrode (7) (Orion, Boston, MA) [12] and a Chemtrix 60A pH meter (8). The vessel was sealed with a specially-designed plexiglas lid, allowing experiments to be conducted in a $\mathrm{CO}_{2}$-free environment. The contents of the vessel were maintained at $25^{\circ} \mathrm{C}$ by recirculation of water from a temperature-controlled bath (9) through the jacket.

An IBM PC-286 (1) was used both to control the Dosimat titrant injection pump and to acquire $\mathrm{pH}$ and volumetric data for each titration. With an analog-to-digital signal conversion board and the appropriate software, it was possible to specify aliquot volume and injection frequency and to control sampling of the $\mathrm{mV}$ output from the $\mathrm{pH}$ meter. For each injection of titrant, the aliquot volume and the resulting $\mathrm{pH}$ were recorded in a data file. Results from a typical titration experiment consisted of a data file containing approximately 200 of these (volume,pH) points.

The presence of $\mathrm{CO}_{2}$ in the headspace of the titration vessel and the titrant reservoir bottles would cause a change in $\mathrm{pH}$ due to $\mathrm{CO}_{2}$ partitioning into the solution [10]. In order to eliminate this effect, the titration vessel and reservoirs were blanketed with argon at a small positive pressure. Argon from a high pressure cylinder passed through a column (13) containing Drierite and acid-gas-specific molecular sieves to remove any residual water and $\mathrm{CO}_{2}$, before passing to a distribution manifold (14) connected to the titration vessel and the titrant reservoir bottles (3).

A temperature bath equipped with a thermostatted heater/mixer unit (10) was used to circulate water at $25^{\circ} \mathrm{C}$ through the titration vessel jacket. The bath was also equipped with a coil for house cold water (11) to provide cooling in the case of ambient temperatures greater than $25^{\circ} \mathrm{C}$.

The Plexiglas lid for the titration vessel was designed and constructed in-house. It is shown in Appendix D. The holes in the lid were specially-machined to fit the various dimensions of the titrant injection line, the $\mathrm{pH}$ probe and the argon lines. During a titration, the lid rested on an O-ring mounted in a groove on the top lip of the titration vessel. Since the operating pressure was only slightly greater than atmospheric, the lid was secured to the titration vessel with Parafilm. However, in the future a compression clamp would be preferable. 
Appendix E describes some important points that must be considered to ensure that the apparatus is properly configured for gathering titration data with minimal experimental error. 


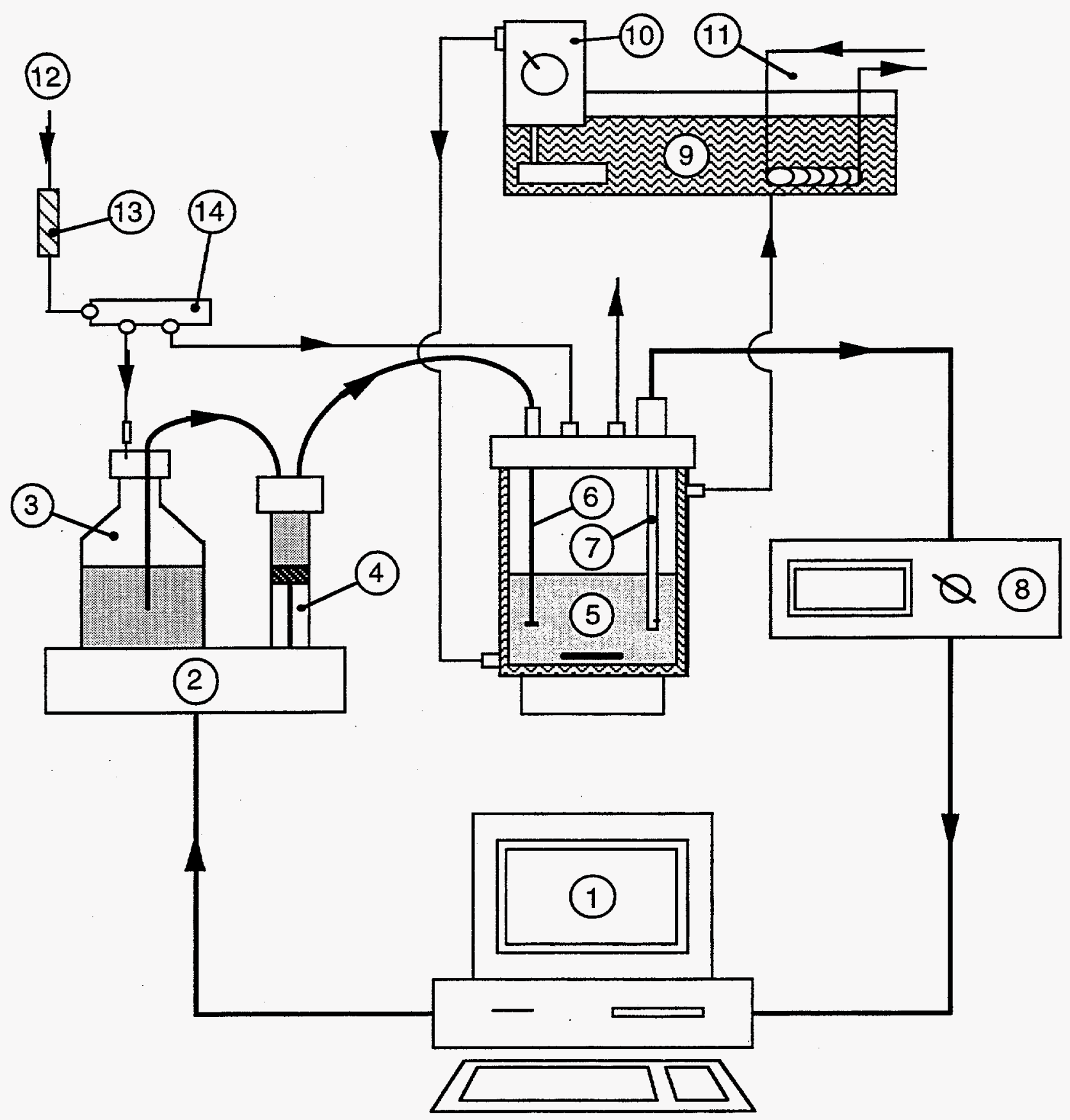

Figure 1: Titration Hardware

(1) IBM PC-286 titration controller

(2) Dosimat 665 injection pump

(3) Titrant reservoir bottle

(4) Injection syringe

(5) Jacketed reaction vessel

(6) Fritted titrant injection line

(7) Ross combination semimicro electrode
(8) Chemtrix $60 \mathrm{~A} \mathrm{pH}$ meter

(9) Water bath

(10) Thermostatted heater/mixer

(11) Cooling water coil

(12) Argon supply

(13) Drierite/molecular sieve column

(14) Gas manifold 


\subsection{Software Description}

The main function of the control software was twofold: to provide automation of the titration equipment; and to gather and record experimental data. Figure $2 \mathrm{~b}$ illustrates the interrelation and succession of all the titration programs and provides a schematic representation of the order and flow of information in each titration experiment. The following sections describe the function of each program and how the output of each program is related to the subsequent program step.

\subsubsection{CAL-TITR}

This program controls the $\mathrm{HCl} / \mathrm{KOH}$ titration necessary to calibrate the $\mathrm{pH}$ electrode before every ligand titration. To perform these calibrations, $\mathrm{HCl}$ was titrated with $\mathrm{KOH}$; initial $\mathrm{pH}$ was always near 2 , and final $\mathrm{pH}$ was always near 12 . Results of the calibration titration were stored in a data file named CALIB.DAT, in the form of volume $\mathrm{KOH}$ added vs. electrode $\mathrm{mV}$ response. The required inputs are the following:

1) Total volume of titrant to be added. The program which calculates the electrode calibration constants (CAL-ANAL) requires 30 volume-added vs. $\mathrm{mV}$-response data points from the $\mathrm{HCl} / \mathrm{KOH}$ titration. Based on this number of points, the $\mathrm{pH}$ range over which it is desired to calibrate the electrode (2-12), the concentration of $\mathrm{HCl}$ and $\mathrm{KOH}$, and the volume of the titration vessel, it was possible to calculate the total volume of titrant $(\mathrm{KOH})$ required to perform a calibration titration. In all cases this volume was $21 \mathrm{~mL}$ since, in all ligand titrations, the parameters mentioned above were.held constant. From this it was possible to calculate the titrant aliquot volume per injection to be $0.7 \mathrm{~mL}$

$(21 \mathrm{~mL} / 30 \mathrm{pts}=0.7 \mathrm{~mL} / \mathrm{pt})$.

2) The delay time between titrant injections. This quantity was chosen to allow enough time for all hydrogen-ion reactions to equilibrate after injection of titrant aliquot. A 40second delay was assumed to be sufficient, for the amino acid and protein ligand titrations, in all cases, as well as for the $\mathrm{HCl} / \mathrm{KOH}$ calibration titration. This was justified by the observation that $\mathrm{mV}$ response after each injection of titrant stopped changing well before 40 seconds had elapsed. 
(1)

Phenolphthalein titration to determine exact $\mathrm{C}_{\mathrm{HCl}}$ and $\mathrm{C}_{\mathrm{KOH}}$ in the titrant solutions

(2)

Strong acid / strong base titration

$(\mathrm{HCl} / \mathrm{KOH})$ over $\mathrm{pH}$ range 2-12

to calibrate the $\mathrm{pH}$ electrode

Figure 2a: Experimental Titration outline

(3)

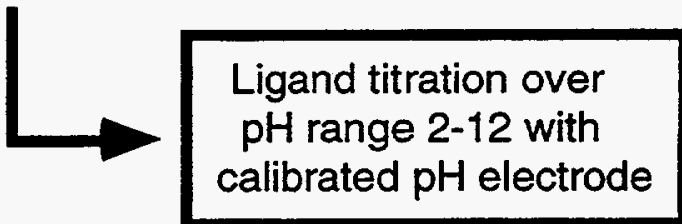

CAL-TITR

(controls $\mathrm{HCl} / \mathrm{KOH}$ titration)

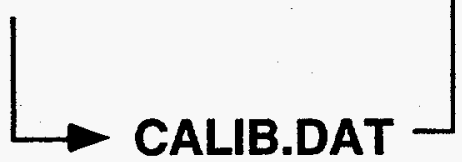

CALIB.DAT

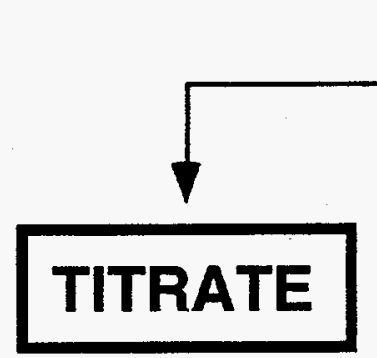

(Controls ligand titrations and gathers volume vs. $\mathrm{p}^{\text {애 }}$ data)
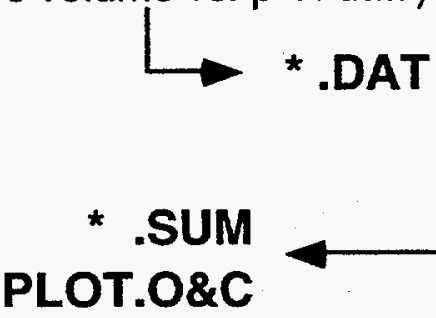

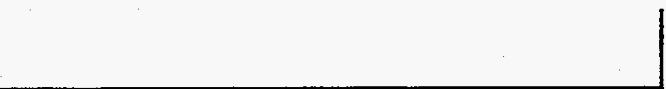

(Calculates electrode slope and intercept from $\mathrm{HCl} / \mathrm{KOH}$ titration)

CALIB.PAR

\section{CAL-ANAL}

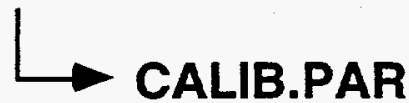

\section{SETUPBTA}

(Prepares data and control parameters for $p^{\circ} K_{a}$ fitting)

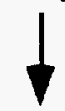

* .INP

\section{BETA90}

(fits $p^{0} K_{a}$ 's)

Figure 2b: Titration software flow sheet ( $*=$ user-defined file name) 
It is important to realize that in the calibration titration, the measured quantity is electrode $\mathrm{mV}$ response to a change in $\mathrm{H}^{+}$concentration, not $\mathrm{pH}$. Before $\mathrm{mV}$ readings could be converted to $\mathrm{p}^{\circ} \mathrm{H}$, the electrode slope and intercept were calculated by the program CALANAL, using the calibration titration results stored by CAL-TITR in the file CALIB.DAT. Further details on the operation of CAL-TITR are provided in Appendix F.

\subsubsection{CAL-ANAL}

This program calculates the $\mathrm{pH}$ electrode slope $\left(\mathrm{mV} / \mathrm{p}^{\circ} \mathrm{H}\right.$ unit) and intercept $\left(\mathrm{E}_{0}\right)$ based on the results of the $\mathrm{HCl} / \mathrm{KOH}$ calibration titration [10]. It performs a non-linear least squares fit of the calibration titration data to the simplified Nernst equation given in $\$ 2$. Required inputs for CAL-ANAL are the following:

1) The volume titrant added vs. $\mathrm{mV}$ response data from the $\mathrm{HCl} / \mathrm{KOH}$ titration. These are read into the program from the file CALIB.DAT created by CAL-TTTR.

2) The exact molar concentrations of $\mathrm{HCl} / \mathrm{KOH}$, given by the potassium hydrogen phthalate/phenolphthalein titration.

3) The initial volume and concentration of $\mathrm{HCl}$ added to the vessel before titration with $\mathrm{KOH}$.

With this information CAL-ANAL converts the volume added data to $\mathrm{p}^{\circ} \mathrm{H}$ and then performs the $\mathrm{p}^{\circ} \mathrm{H} / \mathrm{mV}$ fit to obtain electrode slope and intercept. These are stored in a file named CALIB.PAR, which is needed by the ligand-titration control program, TITRATE.

\subsubsection{TITRATE}

This program controls the titration of ligand (amino acid or protein) with either strong acid or strong base titrant. TITRATE is similar to CAL-TITR described above (see Appendix F). The required inputs are the following:

1) Whether the titration is acidic (decreasing $\mathrm{pH}$ ) or basic (increasing $\mathrm{pH}$ ).

2) Endpoint $\mathrm{pH}$ of the titration. 
3) Aliquot volume for titrant injection. This was chosen small enough to capture the important features of the titration curve, in hopes of optimizing the accuracy of the $\mathrm{p}^{\circ} \mathrm{K}_{\mathrm{a}}$ fitting. Typical $\Delta V$ 's were on the order of $0.4 \mathrm{~mL}$, which yielded between 200 and 300 data points for the whole titration, depending on the ligand.

4) Data file CALIB.PAR. This file contains the slope and intercept for the $\mathrm{pH}$ electrode, calculated by CAL-ANAL. These parameters are necessary to convert the $\mathrm{mV}$ response to addition of a titrant aliquot to $\mathrm{p}^{\circ} \mathrm{H}$ change for each data point in a ligand titration. This file is automatically supplied by CAL-ANAL following the electrode calibration titration described above.

5) Delay time between injections of aliquots. As previously described a delay time of 40 seconds was found to be sufficient for hydrogen-ion reactions to equilibrate in all our ligand titrations.

6) Output data file name *.DAT. Results of the ligand titration are written to a data file with this name (where * is specified by the operator). In this case, the form of saved data for each point is volume titrant added vs. $\mathrm{p}^{\mathrm{O}} \mathrm{H}$. This data file contains all the experimental information necessary to calculate amino acid $\mathrm{p}^{\circ} \mathrm{K}_{a}$ 's.

7) Operating mode of Dosimat pump.

\subsubsection{SETUPBTA}

This program creates an input file for the $\mathrm{p}^{0} \mathrm{~K}_{\mathrm{a}}$ fitting program (BETA90) [10]; the input file name is *.INP. This file contains all the experimental ligand-titration data points in *.DAT, plus further information about the titration conditions and ligand chemistry required for BETA90 to regress ligand $\mathrm{p}^{\circ} \mathrm{K}_{\mathrm{a}}$ 's and protonation states. For further details on the use of SETUPBTA and the contents and format of *INP, see Appendix G.1.

\subsubsection{BETA90}

This program regresses amino acid $\mathrm{p}^{\mathrm{o}} \mathrm{K}_{\mathrm{a}}$ 's from experimental titration data [10]. Based on the data contained in *.INP and initial approximations of the ligand $\mathrm{p}^{\circ} \mathrm{K}_{\mathrm{a}}$ 's, this program iteratively solves for the experimental $\mathrm{p}^{\circ} \mathrm{K}_{\mathrm{a}}$ 's. It fits the ligand $\mathrm{p}^{\circ} \mathrm{K}_{\mathrm{a}}$ 's by minimizing differences between the experimental titration curve and the curve calculated with current values of the $\mathrm{p}^{\circ} \mathrm{K}_{\mathrm{a}}$ 's. It also calculates $\mathrm{p}^{\circ}$ I of the ligand, based on titration data 
and information contained in *.INP. When the best set of $\mathrm{p}^{\circ} \mathrm{K}_{\mathrm{a}}$ 's is found, the program terminates and writes the fit values of $\mathrm{p}^{\circ} \mathrm{K}_{\mathrm{a}}$ 's, the calculated charge vs. $\mathrm{p}^{\circ} \mathrm{H}$ curve calculated from the fit $\mathrm{p}^{\circ} \mathrm{K}_{\mathrm{a}}$ 's and other summary information (quality of fit, \# iterations, etc.) to the output files PLOT.O\&C and *.SUM.

It should be noted that BETA90 in its current form has the ability to treat ligands having 20 or fewer hydrogen ion equilibria [10]. It handles amino acid titrations $\left(3 \mathrm{p}^{\circ} \mathrm{K}_{\mathrm{a}}\right.$ 's) easily, but cannot be applied to our protein titration data (lysozyme $=32 \mathrm{p}^{\circ} \mathrm{K}_{\mathrm{a}}$ 's; chymotrypsin $=43 \mathrm{p}^{\circ} \mathrm{K}_{\mathrm{a}}$ 's). Also BETA90 has the ability to fit $\mathrm{p}^{\circ} \mathrm{K}_{\mathrm{a}}$ 's outside the $\mathrm{p}^{\circ} \mathrm{H}$ range of the experimental titration data, given a reasonable initial estimate. Initial estimates were taken from tabulated values for low ionic strength conditions, found in the literature [7]. Appendix G.2 gives further detail on the operation of BETA90.

\subsection{Experimental Procedure}

Eleven amino acids having thirteen relevant hydrogen-ion equilibria were titrated to determine their $\mathrm{p}^{\circ} \mathrm{K}_{\mathrm{a}}$ 's. Also, lysozyme and $\alpha$-chymotrypsin were titrated to determine their relative charges as a function of $\mathrm{p}^{\mathrm{oH}}$ and for comparison to IST calculations. The titrations were conducted in $\mathrm{KCl}$ solutions at three different ionic strengths: $0.1,1.0$ and 3.0 $M$. Instructions for every step in the experimental titration procedure are found in Appendix H.

To check the amino-acid and protein-titration results for reproducibility, every titration experiment was performed at least twice under the same experimental conditions. If significant differences in amino acid $\mathrm{p}^{\circ} \mathrm{K}_{\mathrm{a}}$ 's $(0.05 \mathrm{pH}$ units) were observed over two titrations, a third titration was performed. 


\section{Results/Discussion}

\section{Amino-Acid Hydrogen-Ion Titration}

Hydrogen-ion titrations were performed over the $\mathrm{p}^{\circ} \mathrm{H}$ range $2-11$ for the 11 amino acids listed in $\S 2$. Of the 29 hydrogen-ion equilibria probed by conducting titrations, 13 were relevant for protein net-charge calculations using the independent-site theory described previously. The $\mathrm{p}^{\circ} \mathrm{K}_{\mathrm{a}}$ 's for these equilibria are listed in Table 1; they are discussed below. The remaining $16 \mathrm{p}^{\circ} \mathrm{K}_{\mathrm{a}}$ 's are tabulated in Appendix $\mathrm{I}$. As indicated in $\S 2$, all $\mathrm{p}^{\circ} \mathrm{K}_{\mathrm{a}}$ 's are expressed in term of concentrations rather than activities.

Figure 3 shows $\mathrm{p}^{\circ} \mathrm{H}$ vs. net charge for a titration of aspartic acid in $3.0 \mathrm{M} \mathrm{KCl}$. The open circles represent experimental titration points $(-200)$ converted from volumetric data to net charge, while the solid line is the fitted curve calculated by BETA90. Generally, the difference between the two curves is much less than $0.05 \mathrm{pH}$ units, as indicated by the dashed line. Near the water-equivalence point, where data are sparse because the $\mathrm{p}^{\circ} \mathrm{H}$ changes rapidly with addition of small titrant aliquots, the error is slightly greater. The $\mathrm{p}^{\circ} \mathrm{K}_{\mathrm{a}}$ 's correspond to points where the $\mathrm{p}^{\circ} \mathrm{H}$ vs. charge curve has an inflection point of minimum slope [7]. Note from Figure 3 that BETA90 has the ability to determine $\mathrm{p}^{\circ} \mathrm{K}_{\mathrm{a}}$ 's which may not be readily observable by examining the titration curve, as in the case of the $\gamma$ carboxyl substituent of aspartic acid $\left(\mathrm{p}^{0} \mathrm{~K}_{\mathrm{a}}=3.95\right)$. (Refer to $\S 3.2 .5$ above and Appendix G.2 for further details on the BETA90 curve-fitting algorithm and $\mathrm{p}^{\circ} \mathrm{K}_{\mathrm{a}}$ refinement)

Table 1 shows the experimental $\mathrm{p}^{\circ} \mathrm{K}_{\mathrm{a}}$ values of interest in IST net-charge calculations for lysozyme and $\alpha$-chymotrypsin. Results are shown for three different values of $\mathrm{KCl}$ ionic strength: $0.1 \mathrm{M}, 1.0 \mathrm{M}$ and $3.0 \mathrm{M}$. At each ionic strength each amino acid was titrated at least twice for reproducibility. A third titration was performed in cases where the first two $\mathrm{p}^{\circ} \mathrm{K}_{\mathrm{a}}$ 's measured were different by more than $0.05 \mathrm{pH}$ units. In Table 1, all measured $\mathrm{p}^{0} \mathrm{~K}_{\mathrm{a}}$ 's are shown for each amino acid, for completeness. The boldfaced numbers are the values of $\mathrm{p}^{0} \mathrm{~K}_{\mathrm{a}}$ chosen for use in the theoretical calculations of protein net charge. For titrations where the first two $\mathrm{p}^{\circ} \mathrm{K}_{\mathrm{a}}$ 's measured differ by less than $0.05 \mathrm{pH}$ units, the chosen value was the average of the two. However, in the case where a third titration was necessary, an appropriate average was taken, depending on the resulting $\mathrm{p}^{\circ} \mathrm{K}_{\mathrm{a}}$ 's and on an estimation of experimental error (quality of fit). 


\begin{tabular}{|c|c|c|c|c|c|c|c|}
\hline $\begin{array}{l}\text { AMINO ACID } \\
\text { (titrated moiety) }\end{array}$ & $\begin{array}{r}\text { IS } \\
\text { Experi }\end{array}$ & $\begin{array}{l}=0.1 \mathrm{~N} \\
\text { lent }\end{array}$ & Lit. & \multicolumn{2}{|c|}{$\mathrm{IS}=1.0 \mathrm{M}$} & \multicolumn{2}{|c|}{$\overline{I S}=3.0 \mathrm{M}$} \\
\hline $\begin{array}{l}\text { Alanine } \\
\text { (amino)* }\end{array}$ & $\begin{array}{l}9.85 \\
9.88\end{array}$ & 9.86 & 9.69 & $\begin{array}{l}9.74 \\
9.78\end{array}$ & 9.76 & $\begin{array}{l}10.06 \\
10.13\end{array}$ & 10.1 \\
\hline $\begin{array}{c}\text { Arginine } \\
\text { (substituent) }\end{array}$ & $\begin{array}{l}13.42 \\
12.68 \\
12.87\end{array}$ & 12.7 & & $\begin{array}{l}12.76 \\
12.44 \\
13.40\end{array}$ & 12.9 & $\begin{array}{l}12.82 \\
12.85\end{array}$ & 12.83 \\
\hline $\begin{array}{l}\text { Asparagine } \\
\text { (carboxyl) }\end{array}$ & $\begin{array}{l}2.18 \\
2.19\end{array}$ & 2.18 & 2.14 & $\begin{array}{l}2.35 \\
2.28 \\
2.27\end{array}$ & 2.3 & $\begin{array}{l}2.45 \\
2.47\end{array}$ & 2.46 \\
\hline $\begin{array}{c}\text { Aspartic Acid } \\
\text { (substituent)* }\end{array}$ & $\begin{array}{l}3.73 \\
3.72\end{array}$ & 3.72 & 3.70 & $\begin{array}{l}3.65 \\
3.70 \\
\end{array}$ & 3.67 & $\begin{array}{l}3.95 \\
3.94\end{array}$ & 3.95 \\
\hline $\begin{array}{l}\text { Cysteine } \\
\text { (amino)* }\end{array}$ & $\begin{array}{l}10.25 \\
10.44 \\
10.40\end{array}$ & 10.42 & 10.29 & $\begin{array}{l}10.22 \\
10.29\end{array}$ & 10.26 & $\begin{array}{l}10.37 \\
10.28 \\
10.51\end{array}$ & 10.4 \\
\hline $\begin{array}{c}\text { Glutamic Acid } \\
\text { (substituent)* }\end{array}$ & $\begin{array}{l}4.18 \\
4.16\end{array}$ & 4.17 & 4.20 & $\begin{array}{l}4.06 \\
4.15 \\
4.14\end{array}$ & 4.14 & $\begin{array}{l}4.44 \\
4.43\end{array}$ & 4.43 \\
\hline $\begin{array}{c}\text { Histidine } \\
\text { (substituent) }\end{array}$ & $\begin{array}{l}6.06 \\
6.06\end{array}$ & 6.06 & 6.02 & $\begin{array}{l}6.28 \\
6.23 \\
\end{array}$ & 6.26 & $\begin{array}{l}6.62 \\
6.58 \\
\end{array}$ & 6.60 \\
\hline $\begin{array}{l}\text { Isoleucine } \\
\text { (amino) }\end{array}$ & $\begin{array}{l}9.63 \\
9.65\end{array}$ & 9.64 & 9.62 & $\begin{array}{l}9.76 \\
9.68 \\
9.73\end{array}$ & 9.71 & $\begin{array}{l}10.06 \\
10.03\end{array}$ & 10.04 \\
\hline $\begin{array}{c}\text { Leucine } \\
\text { (carboxyl) }\end{array}$ & $\begin{array}{l}2.33 \\
2.32\end{array}$ & 2.33 & 2.35 & $\begin{array}{l}2.44 \\
2.43\end{array}$ & 2.43 & $\begin{array}{l}2.70 \\
2.70\end{array}$ & 2.70 \\
\hline $\begin{array}{l}\text { Lysine } \\
\text { (amino) }\end{array}$ & $\begin{array}{l}9.22 \\
9.21\end{array}$ & 9.21 & 9.08 & $\begin{array}{l}9.37 \\
9.40\end{array}$ & 9.38 & $\begin{array}{l}9.71 \\
9.74\end{array}$ & 9.72 \\
\hline (substituent) & $\begin{array}{l}10.83 \\
10.79\end{array}$ & 10.81 & 10.69 & $\begin{array}{l}10.85 \\
10.84\end{array}$ & 10.85 & $\begin{array}{l}11.04 \\
10.95 \\
11.05\end{array}$ & 11.04 \\
\hline $\begin{array}{l}\text { Tyrosine } \\
\text { (carboxyl) }\end{array}$ & $\begin{array}{l}2.34 \\
2.10\end{array}$ & 2.3 & 2.17 & $\begin{array}{l}2.29 \\
2.38\end{array}$ & 2.3 & $\begin{array}{l}2.59 \\
2.64\end{array}$ & 2.62 \\
\hline (substituent)* & $\begin{array}{l}10.18 \\
10.15\end{array}$ & 10.17 & 10.14 & $\begin{array}{l}10.02 \\
10.02\end{array}$ & 10.02 & $\begin{array}{l}10.21 \\
10.15\end{array}$ & 10.18 \\
\hline
\end{tabular}

Table 1: Summary of amino-acid titration results, showing experimental $\mathrm{p}^{\circ} \mathrm{K}_{\mathrm{a}}$ 's as a function of $\mathrm{KCl}$ concentration. Literature values for $\mathrm{IS}=0.1 \mathrm{M}$ are shown for comparison [4]. The $\mathrm{p}^{\circ} \mathrm{K}_{\mathrm{a}}$ 's shown here are the values necessary for IST calculations of protein net charge. More complete data are found in Appendix I. The amino-acid concentrations in the hydrogen-ion titrations are $10 \mathrm{mM}$, except Tyrosine $2 \mathrm{mM}$ and Alanine, Isoleucine and Leucine $20 \mathrm{mM}$ 
In most titrations, reproducibility of $\mathrm{p}^{\circ} \mathrm{K}_{\mathrm{a}}$ 's was high. However, two special cases are worthy of distinction. For the arginine $\varepsilon$-imino group, the $\mathrm{p}^{\circ} \mathrm{K}_{\mathrm{a}}$ is near 13 . This was the most basic $\mathrm{p}^{\circ} \mathrm{K}_{\mathrm{a}}$ probed in all our measurements and was well outside the $\mathrm{p}^{\circ} \mathrm{H}$ range of our titrations. Therefore the uncertainty in BETA90 $\mathrm{p}^{\mathrm{o}} \mathrm{K}_{\mathrm{a}}$ fitting for this moiety was much higher than for equilibria with less extreme $\mathrm{p}^{\circ} \mathrm{K}_{\mathrm{a}}$ 's, especially in the $0.1 \mathrm{M}$ and $1.0 \mathrm{M}$ cases. Also, it proved very difficult for BETA90 to perform $\mathrm{p}^{\circ} \mathrm{K}_{\mathrm{a}}$ fitting for tyrosine in 0.1 $\mathrm{M} \mathrm{KCl}$. Of the 5 tyrosine titrations conducted at this ionic strength, only two yielded values for $\mathrm{p}^{\circ} \mathrm{K}_{\mathrm{a}}$ 's of the carboxyl-endgroup and phenolic-substituent equilibria. Consequently, great variation was seen in the carboxyl $\mathrm{p}^{0} \mathrm{~K}_{\mathrm{a}}$; the value 2.3 was chosen since it had a lower G.O.F.. This abnormal behavior may be a consequence of the very low solubility of tyrosine $(0.5 \mathrm{mM})$.

Table 1 also shows comparison of $\mathrm{p}^{\circ} \mathrm{K}_{\mathrm{a}}$ 's measured in $0.1 \mathrm{M} \mathrm{KCl}$ at $25^{\circ} \mathrm{C}$ to values found in the literature [4]. In many cases the measured $\mathrm{p}^{\circ} \mathrm{K}_{\mathrm{a}}$ 's agree with the literature values to within a few hundredths of a $\mathrm{pH}$ unit, while the remaining $\mathrm{p}^{\circ} \mathrm{K}_{\mathrm{a}}$ 's differ by at most $0.15 \mathrm{pH}$ units. Based on this substantial agreement between our titration and fitting results and the literature values, we are confident that the $\mathrm{p}^{0} \mathrm{~K}_{\mathrm{a}}$ values shown in Table 1 for amino acids in $1.0 \mathrm{M}$ and $3.0 \mathrm{M} \mathrm{KCl}$ solutions are accurate, as well.

We observed that several amino acid hydrogen ion equilibria showed an initial decrease in $\mathrm{p}^{0} \mathrm{~K}_{\mathrm{a}}$ 's as ionic strength rises from $0.1 \mathrm{M}$ to $1.0 \mathrm{M}$, followed by an increase as the ionic strength rises to $3.0 \mathrm{M}$. The $\mathrm{p}^{\circ} \mathrm{K}_{\mathrm{a}}$ at $3.0 \mathrm{M}$ is generally higher than the value at $0.1 \mathrm{M}$. It is important to note that not all equilibria exhibit this effect, many demonstrate a simple steady increase in $\mathrm{p}^{\circ} \mathrm{K}_{\mathrm{a}}$ with increasing ionic strength. There seems to be no generalization in the chemistry of the amino acids with which to correlate this behavior. The equilibria exhibiting this effect are denoted with an asterisk on Table 1.

Martell and Smith noted similar trends for certain amino-acid hydrogen-ion equilibria in their review of the amino-acid titration literature [4]. They also found that, for many simple amino acids, certain $\mathrm{p}^{0} \mathrm{~K}_{\mathrm{a}}$ 's decrease with increasing ionic strength and reach a minimum near IS $=0.5 \mathrm{M}$, followed by a steady increase as ionic strength goes to $3.0 \mathrm{M}$. Literature data is extremely rare for $\mathrm{p}^{\circ} \mathrm{K}_{\mathrm{a}}$ 's in solutions of IS $>3.0 \mathrm{M}$ [4]. They show that, in these cases, $\mathrm{p}^{\circ} \mathrm{K}_{\mathrm{a}}$ values are often nearly equal at IS $=0.1 \mathrm{M}$ and at $\mathrm{IS}=1.0 \mathrm{M}$. It may be possible to explain this behavior by considering the effect of electrolyte concentration on the activity of the hydrogen ion. Recall that in $\S 2$, we asserted that $\gamma_{\mathrm{H}^{+}}$was constant over a given titration. However, $\gamma_{\mathrm{H}^{+}}$is a function of ionic strength and differs for titrations of 
different IS. If we define our hydrogen-ion equilibrium constant, $\mathrm{K}_{\mathrm{a}}$, for a specific moiety in a given titration as [9]:

$$
K_{a}=\frac{c_{A^{-}} \cdot c_{H^{+}}}{c_{H A}} \cdot \frac{\gamma_{A^{-}} \cdot \gamma_{H^{+}}}{\gamma_{H A}}=K_{a}^{o} \cdot \frac{\gamma_{A^{-}} \cdot \gamma_{H^{+}}}{\gamma_{H A}}
$$

and make the assumption that ligand is very dilute with respect to electrolyte (typical ligand concentration were $\sim 0.5-5 \mathrm{mM}$ ), then it is appropriate to assume ligand activity coefficients are equal to unity, and thus equation (19) reduces to:

$$
K_{a}=K_{a}^{o} \cdot \gamma_{H^{+}}
$$

Since $K_{a}$ is based on activity and therefore a function of temperature only, we see that changes in $\mathrm{K}^{\circ} \mathrm{a}$ with changing electrolyte concentration must be counterbalanced by appropriate changes in $\gamma_{\mathrm{H}}+$ [7]. Under these assumptions, it is possible to quantify approximate changes in $\gamma_{\mathrm{H}^{+}}$as ionic strength increases, in the following manner:

$$
\Delta p^{o} K_{a}=\left(p^{o} K_{a}\right)_{I S 2}-\left(p^{o} K_{a}\right)_{I S 1}=-\log \left[\frac{\left(\gamma_{H^{+}}\right)_{I S 1}}{\left(\gamma_{H^{+}}\right)_{I S 2}}\right]
$$

From the data in Table 1 we estimate that $\gamma_{\mathrm{H}^{+}}$decreases by roughly $20 \%$ as ionic strength goes from $0.1 \mathrm{M}$ to $1.0 \mathrm{M}$ and increases by roughly $50 \%$ as ionic strength increases from $1.0 \mathrm{M}$ to $3.0 \mathrm{M}$ depending on the equilibrium examined. In general, these activity arguments should be valid for all hydrogen-ion equilibria. However, as previously mentioned, it is not presently known why some equilibria show this trend in $\mathrm{p}^{\circ} \mathrm{K}_{\mathrm{a}}$, while others demonstrate a steady increase with ionic strength instead.

\section{Independent-Site Theory}

After we determined the relevant $\mathrm{p}^{\circ} \mathrm{K}_{\mathrm{a}}$ 's shown in Table 1 , it was possible to calculate the protein net charge as a function of $\mathrm{p}^{\circ} \mathrm{H}$ using the independent-site theory. Figures $4 \mathrm{a}$ and $4 \mathrm{~b}$ show these calculated hydrogen-ion titration curves of $\alpha$-chymotrypsin and lysozyme for three different solutions of $\mathrm{KCl}$ at $0.1 \mathrm{M}, 1.0 \mathrm{M}$ and $3.0 \mathrm{M}$ ionic strength. 
In both diagrams the titration curves for $0.1 \mathrm{M}$ and $1.0 \mathrm{M}$ ionic strength overlap almost completely, because the amino-acid $\mathrm{p}^{\circ} \mathrm{K}_{\mathrm{a}}$ 's are relatively the same for both ionic strength solutions. Note that the $\mathrm{p}^{\circ} \mathrm{K}_{\mathrm{a}}$ 's determine the shape of the curves predicted by the IST as discussed in $\S 2$. At the $\mathrm{pH}$ extremes, the protein is either totally protonated or unprotonated because the calculated titration curve covers the full range of $\mathrm{p}^{0} \mathrm{~K}_{\mathrm{a}}$ 's. The three different curves of Figures $4 \mathrm{a}$ and $4 \mathrm{~b}$ meet at the endpoints where the protein has either its maximum (low $\mathrm{p}^{\mathrm{o}} \mathrm{H}$ ) or minimum (high $\mathrm{p}^{\mathrm{O}} \mathrm{H}$ ) charge.

The 3.0M-ionic-strength titration curves differ from those curves of the lower ionic strengths in the regions of $\mathrm{p}^{\circ} \mathrm{H} 2$ to 5 and 9 to 11.5 , where most of the $\mathrm{p}^{\circ} \mathrm{K}_{\mathrm{a}}$ values are found. The accumulation of $\mathrm{p}^{\circ} \mathrm{K}_{\mathrm{a}}$ 's in these two regions will magnify the net charge difference. Since the $\mathrm{p}^{0} \mathrm{~K}_{\mathrm{a}}$ 's are the highest in the $3.0 \mathrm{M}$ ionic-strength salt solution, the respective curve for IS=3.0 M will be shifted to the right of the lower ionic strength curves.

A special point of interest in every protein titration is the isoelectric point, pI, defined as the $\mathrm{pH}$ where the net charge is equal to zero. With the IST calculations the $\mathrm{p}$ I of lysozyme and $\alpha$-chymotrypsin can be determined even for high ionic strength, where conventional isoelectric focusing fails. The results are collected in Table 2. Since the IST calculates the $\mathrm{p}^{\circ}$ I from free amino-acid $\mathrm{p}^{\circ} \mathrm{K}_{\mathrm{a}}$ 's, the $\mathrm{p}^{\circ}$ I values are the same for IS $=0.1 \mathrm{M}$ and $1.0 \mathrm{M}$, whereas the $\mathrm{p}^{\mathrm{O} I}$ is higher for the $3.0 \mathrm{M}$ ionic strength.

\begin{tabular}{|lccc|}
\hline & IS=0.1M & IS=1.0M & IS=3.0M \\
\cline { 2 - 4 } Lysozyme & 11.131 & 11.159 & 11.311 \\
$\alpha$-Chymotrypsin & 9.676 & 9.625 & 9.831 \\
\hline
\end{tabular}

Table 2: Calculated poI's for lysozyme and $\alpha$-chymotrypsin using IST

\section{Comparison to Protein Hydrogen-Ion Titrations}

Protein hydrogen-ion titrations yield data points consisting of the volume of titrant added and the corresponding $\mathrm{p}^{\circ} \mathrm{H}$ response. In order to calculate protein net charge as a 
function of $\mathrm{p}^{\mathrm{oH}}$ for the purpose of comparing theory to experiment, it was necessary to convert volumetric data to charge data. This was done simply as follows.

In a basic protein titration every aliquot of $\mathrm{KOH}$ titrant added contains a discrete number of $\mathrm{OH}^{-}$-ions, $\mathrm{n}_{\mathrm{OH}}$. Some of these injected $\mathrm{OH}^{-}$-ions, $\mathrm{n}_{\Delta \mathrm{pH}}$, will raise the $\mathrm{p}^{\circ} \mathrm{H}$ of the solution by the observed value $\Delta \mathrm{p}^{\circ} \mathrm{H}$. The remaining number of $\mathrm{OH}^{-}$-ions, $\mathrm{n}_{\Delta z}$, will react with the titratable groups of the proteins to change their net charge by $\Delta z$, as illustrated below:

$\mathrm{OH}^{-}$-ions

in basic titrant aliquot

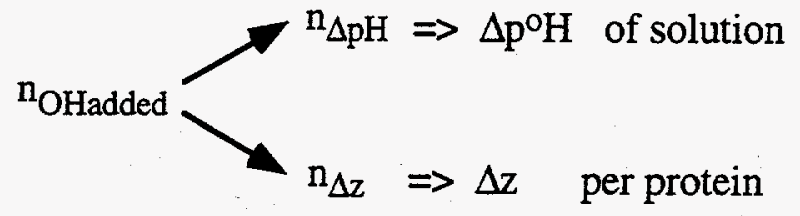

$$
n_{O H}=n_{\Delta z}+n_{\Delta p H}
$$

For a known amount of protein in the solution, $\mathrm{n}_{\mathrm{prot}}$, the change in net charge of one protein is then:

$$
\Delta z=\frac{n_{\Delta z}}{n_{\text {prot }}}=\frac{n_{\text {OHadded }}-n_{\Delta p H}}{n_{\text {prot }}}
$$

The change of the net charge for a protein molecule titrated from starting point ' 0 ' ( $\left.\mathrm{p}^{\circ} \mathrm{H}_{0} ; \mathrm{mL}_{\mathrm{O}}\right)$ to any point ' $\mathrm{i}$ ' $\left(\mathrm{p}^{\circ} \mathrm{H}_{\mathrm{i}} / \mathrm{mL}_{\mathrm{i}}\right)$ can be calculated as follows.

The amount of $\mathrm{OH}^{-}$-ions added in one or more aliquots of basic titrant $(\mathrm{KOH})$ till point ' $i$ ' is reached:

$$
n_{\text {OHadded }}=m L_{\text {added }} \cdot c_{\text {KOH }}
$$

The amount of $\mathrm{OH}^{-}$-ions needed to raise the solution $\mathrm{p}^{\circ} \mathrm{H}$ from $\mathrm{p}^{\circ} \mathrm{H}_{0}$ to $\mathrm{p}^{\circ} \mathrm{H}_{\mathrm{i}}$ :

$$
n_{\triangle p H}=n_{O H i}-n_{O H 0}=V_{i} \cdot c_{O H i}-V_{0} \cdot c_{O H 0}
$$

with

$$
K_{W}^{o}=\left[H^{+}\right] \cdot\left[O H^{-}\right] \text {and } V_{i}=V_{0}+m L_{\text {added }}
$$

follows that

$$
n_{\Delta p H}=\left(V_{0}+m L_{a d d e d}\right) \frac{K^{o} w}{10^{-p^{o} H_{i}}}-V_{0} \frac{K^{o} w}{10^{-p^{o} H_{0}}}
$$


and therefore the change of the net charge for one titrated protein molecule is:

$$
\Delta z=\frac{\Delta m L_{\text {added }} \cdot c_{K O H}-\left[\left(V_{0}+m L_{\text {added }}\right) \frac{K^{o} w}{10^{-p^{o} H_{i}}}-V_{0} \frac{K^{o} w}{10^{-p^{o} H_{0}}}\right]}{n_{\text {prot }}}
$$

Using this equation, only the net charge differences $\Delta z$, relative to the starting point of the titration, could be calculated; in a basic titration $\Delta z$ is always negative. These $\Delta z / p^{\circ} H$ titration data can only be converted into a absolute net-charge/ $/ \mathrm{p}^{\circ} \mathrm{H}$ titration curve if one absolute net charge is known for a certain $\mathrm{p}^{\circ} \mathrm{H}$. In low ionic-strength solutions, it is possible to measure poI by isoelectric-focusing electrophoresis. However, this is not possible in high ionic-strength solutions. Therefore, for the purpose of comparing experimental protein titration curves with our IST, the experimental poI's of the proteins were considered as a first approximation to be equal to the ones calculated from the IST. The calculated poI's for lysozyme and $\alpha$-chymotrypsin are shown in Table 2.

With this knowledge, equation (14) can now be extended by an intercept $t$, allowing to calculate absolute net charge $\mathrm{z}_{\text {net }}$ as a function of $\mathrm{p}^{\circ} \mathrm{H}$ :

$$
z_{\text {net }}=\frac{\Delta m L_{\text {added }} \cdot c_{K O H}-\left[\left(V_{0}+m L_{\text {added }}\right) \frac{K^{o} W}{10^{-p^{0} H_{i}}}-V_{0} \frac{K^{o} W}{10^{-p^{o} H_{0}}}\right]}{n_{\text {prot }}}+t
$$

The intercept $t$ is chosen so that the absolute charge $z_{\text {net }}$ is zero when $\mathrm{p}^{\circ} \mathrm{H}$ equals the $\mathrm{p}^{\circ} \mathrm{I}$ calculated via IST.

The experimental data of a protein hydrogen-ion titration can be compared to the calculated titration curve based on the IST by plotting these two curves in the same diagram fitted together at the calculated poI. Figures $5 \mathrm{a}$ and $5 \mathrm{~b}$ show experimental and calculated titration results for lysozyme in $\mathrm{KCl}$ solutions of $\mathrm{IS}=0.1 \mathrm{M}$ and $\mathrm{IS}=1.0 \mathrm{M}$. The IST results fit the experimental data well in the lower ionic strength $(0.1 \mathrm{M})$. The IST seems to be more sensitive to $\mathrm{p}^{\mathrm{o}} \mathrm{H}$ changes than the experimental protein titration, which is depicted by the sharper bends in the IST graph. Furthermore literature data [13] of IS=0.15 added to the graphs show that the general tendency of the IST is correct. In this low ionic strength, the calculation based on free amino-acid $\mathrm{p}^{0} \mathrm{~K}_{2}$ 's can be seen as a success for the simplicity and 
large assumptions of our model. In IS $=1.0 \mathrm{M}$ the calculated and measured curve still conform in the region between $\mathrm{p}^{\circ} \mathrm{H} 4$ and 11.3. The deviation in this section can be explained by the $\mathrm{p}^{\text {ol }}$ being fixed in the steep part of the curve so that small experimental inaccuracies would cause a discernible vertical shift. The acidic and basic ends of the measured protein titration curve, however, differ by larger amounts. This difference is even higher in IS=3.0, making a graphic illustration for this ionic strength useless.

Figures $6 \mathrm{a}$ and $6 \mathrm{~b}$ show measured and calculated titration curves of chymotrypsin in two higher ionic strengths (1.0M and 3.0M). Both diagrams display similar characteristics. Again the IST fulfills the general titration-curve tendencies especially in the $\mathrm{p}^{\circ} \mathrm{H}$ range from 4 to 11. For this protein the deviation of the IST seems to be independent of the increasing ionic strength. There is a drift in the acidic region of the titration curve similar to that of lysozyme in IS=1.0 M KCl. The experimental titration is more likely to be at fault. For example at a $\mathrm{p}^{\circ} \mathrm{H}$ below 3.5 for chymotrypsin an absolute net charge of 30 is observed. This is impossible since chymotrypsin contains only 22 titratable groups in its amino-acid sequence which can be positively charged. The higher value of the net charge stretches the protein-titration curve leading to a deviation that makes a comparison to the calculated curve impossible. These errors can be explained by the special protein peculiarities, e.g. the folded structure [6]. Taking this into account goes beyond the scope of this work. Thus, in high ionic strength an assessment of the IST fails because of the incorrect protein titration curves.

Figure 7 illustrates the reproducibility of two $\alpha$-chymotrypsin experiments in the same 1.0M ionic strength. Because we know the plots are wrong, yet reproducible, proteins can not be titrated with the simple procedure used for the amino-acid titrations. Therefore further development of protein titration methods using the available equipment is necessary.

The IST has been shown to be quantitative in low ionic strength, but for high ionic strength, without an accurate experimental titration curve, it is hard to determine the IST's effectiveness. 


\section{Comparison of Basic and Acidic Protein Titration}

Even if the experimental titration curves show consistent error, it is still possible to observe basic trends of the hydrogen-ion titration behavior. This is reasonable, because in most of the protein titrations performed, the reproducibility was high as mentioned above.

Figure 8 shows a basic (increasing $\mathrm{p}^{\circ} \mathrm{H}$ ) and subsequent acidic (decreasing $\mathrm{p}^{\circ} \mathrm{H}$ ) titration of an $\alpha$-chymotrypsin protein solution in $1.0 \mathrm{M}$ ionic strength. For illustration, the basic titration curve is again fixed on the calculated $\mathrm{p}^{\circ} \mathrm{I}$ of the IST. The starting point of the acidic titration curve was fitted to the end point of the previously conducted basic titration because the net charge of the protein does not change between the end of the basic titration and the beginning of the acidic titration. We observed that the basic and acidic titration curves differ for most of the titration range, but converge again in the acidic extreme of the titration when all titratable groups are protonated and the maximum net charge is reached.

The deviation between the curves might be due to hysteresis effects, caused by reversible changes in the protein molecule configurations [6]. It is also possible that irreversible configuration changes happen in the basic extreme of the titration. 


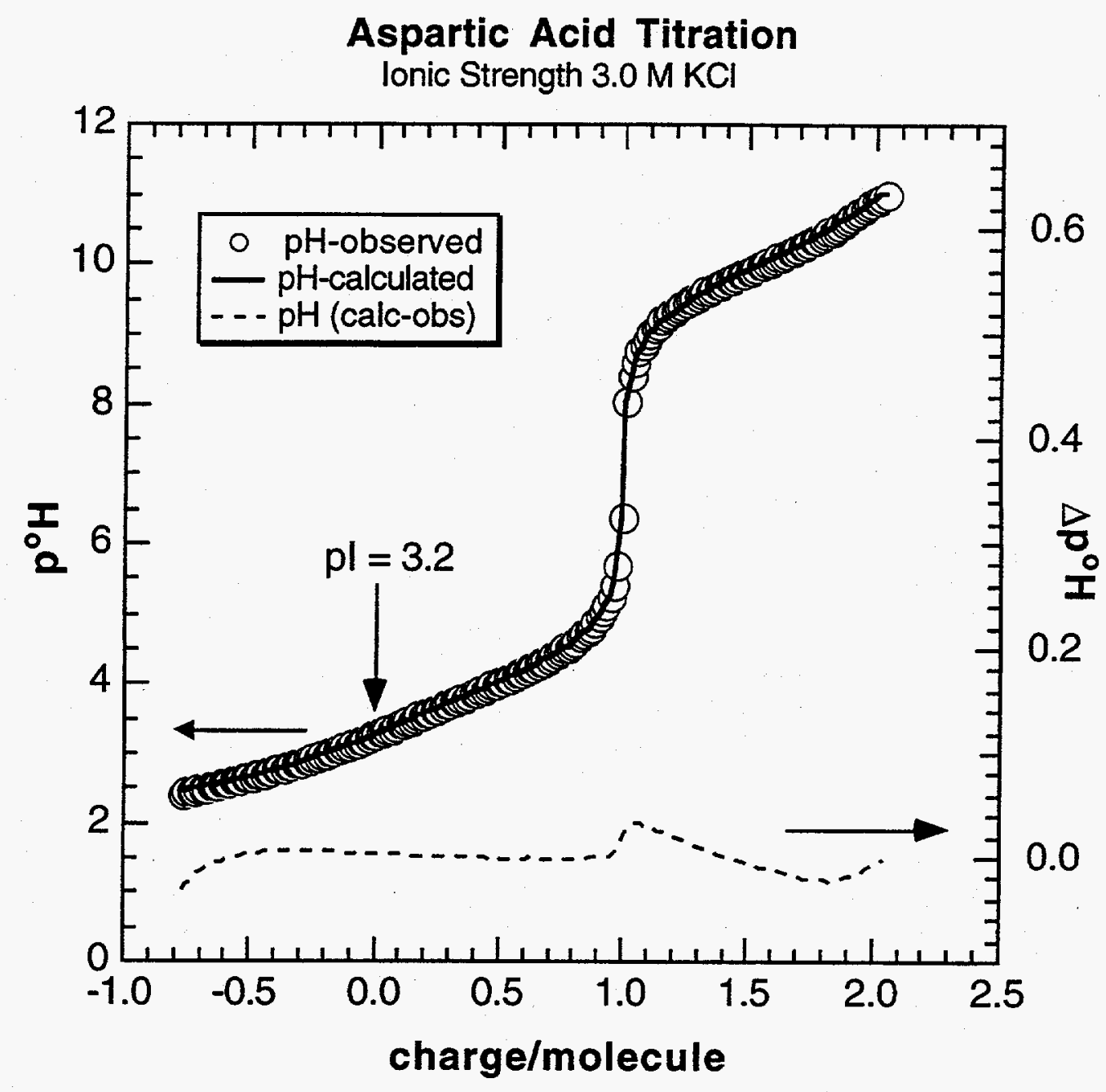

Figure 3: Obtained and calculated titration curve for aspartic acid in $3.0 \mathrm{M} \mathrm{KCl}$ 


\section{Calculated IST Titration Curves}
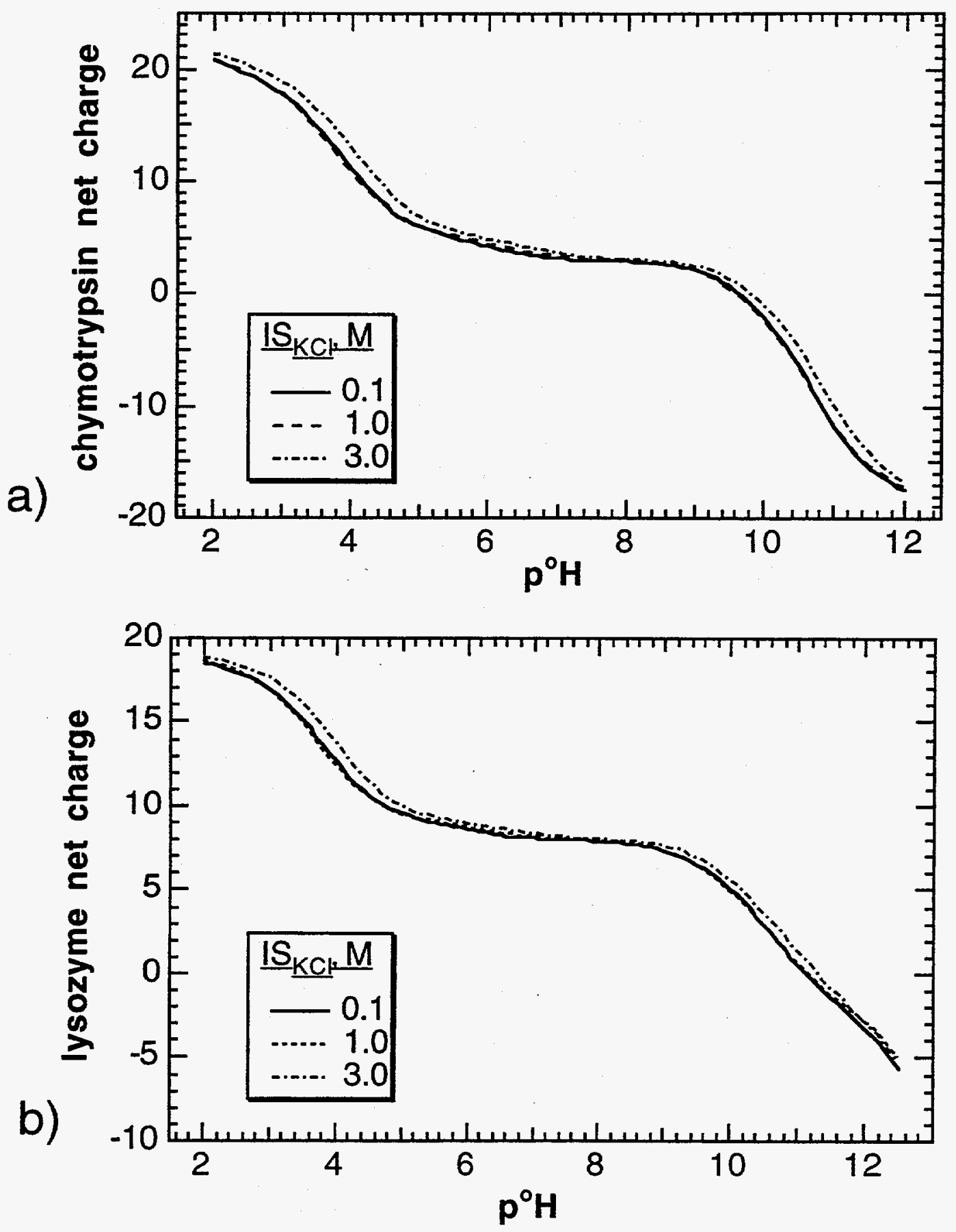

Figure 4: Calculated IST hydrogen-ion titration curves in ionic strength $0.1 \mathrm{M}, 1.0 \mathrm{M}$ and $3.0 \mathrm{M} \mathrm{KCl}$ for a) a-chymotrypsin and b) lysozyme 


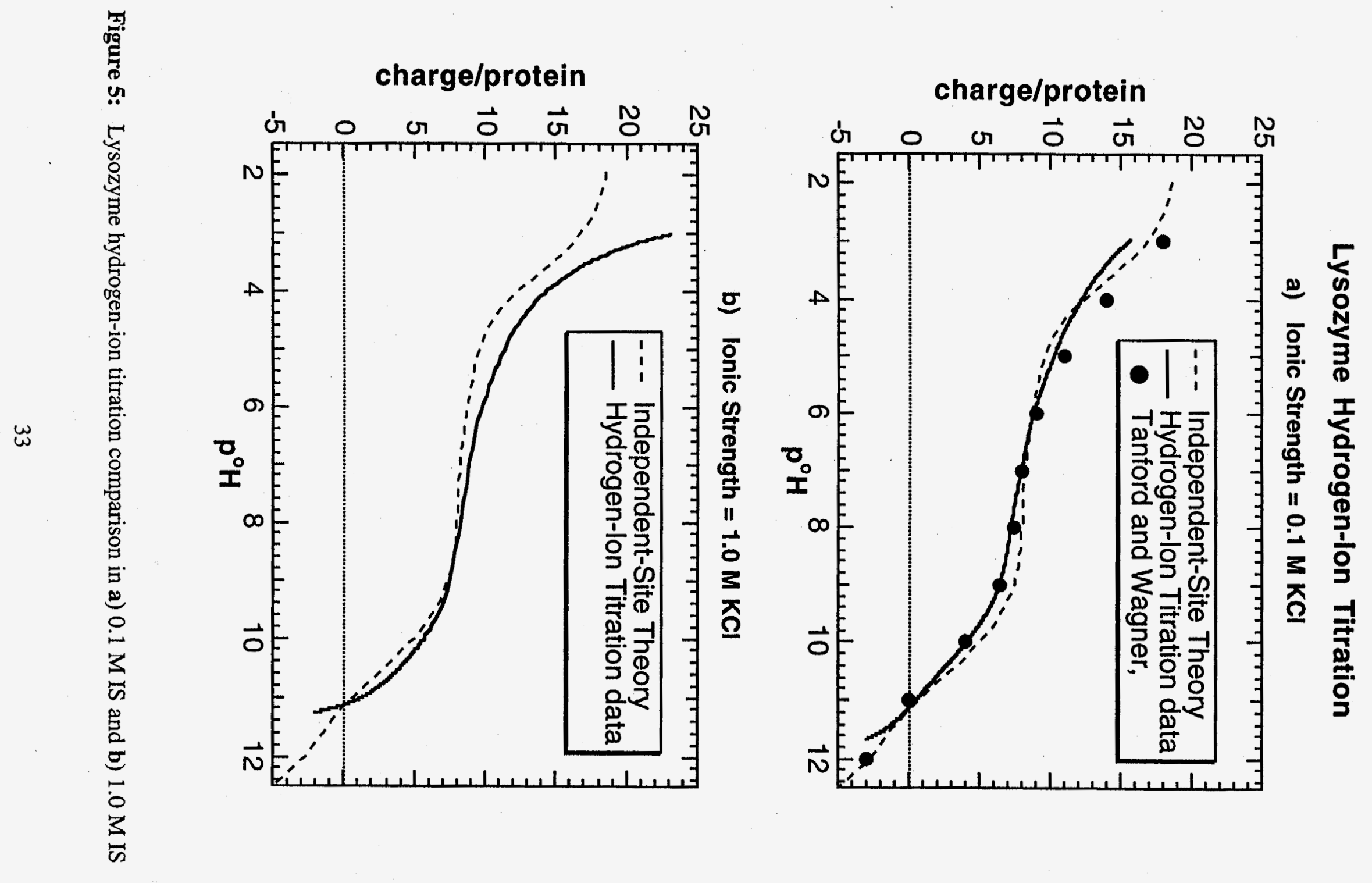


$\alpha$-Chymotrypsin Hydrogen-Ion Titration

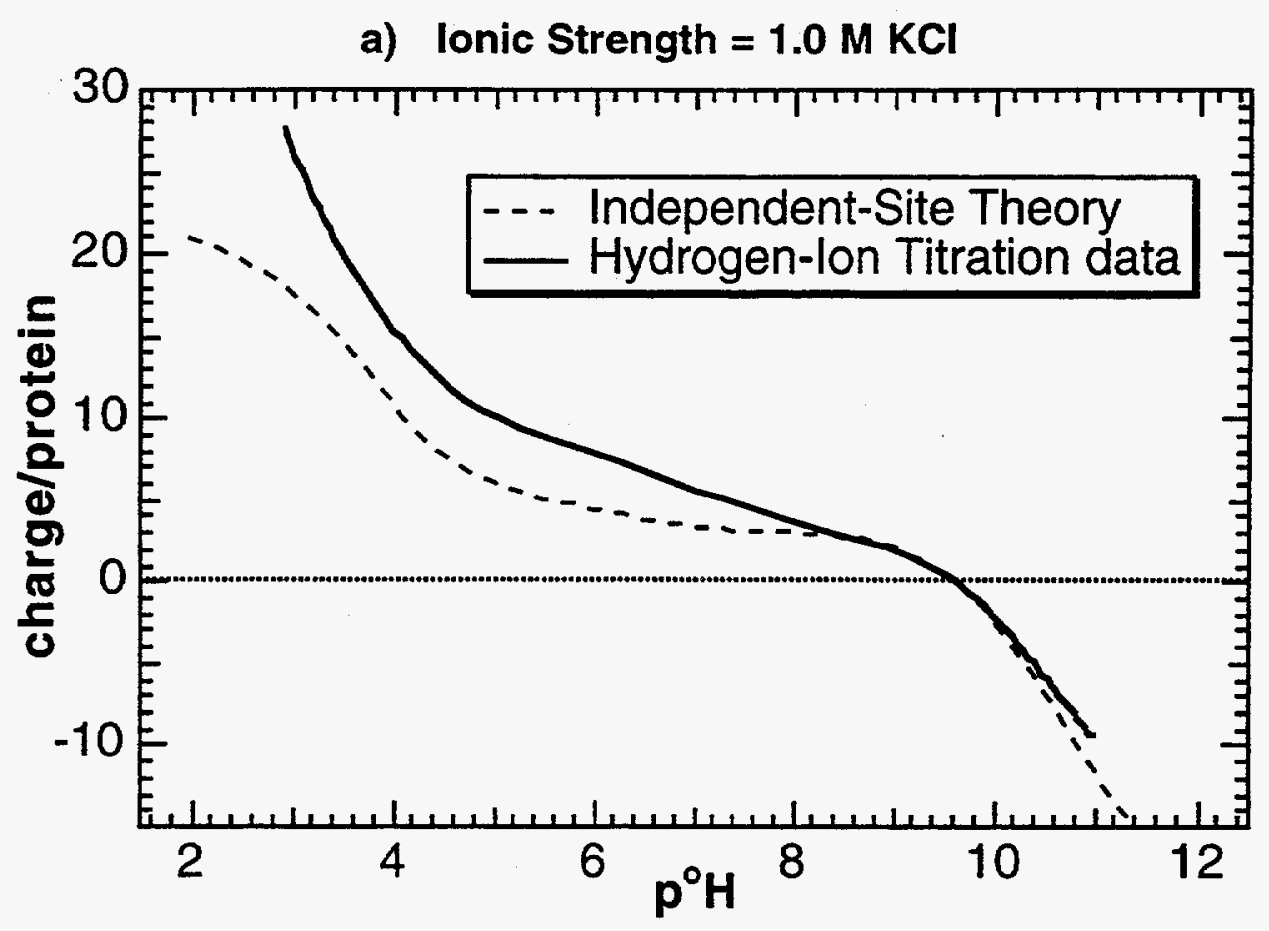

b) Ionic Strength $=3.0 \mathrm{M} \mathrm{KCl}$

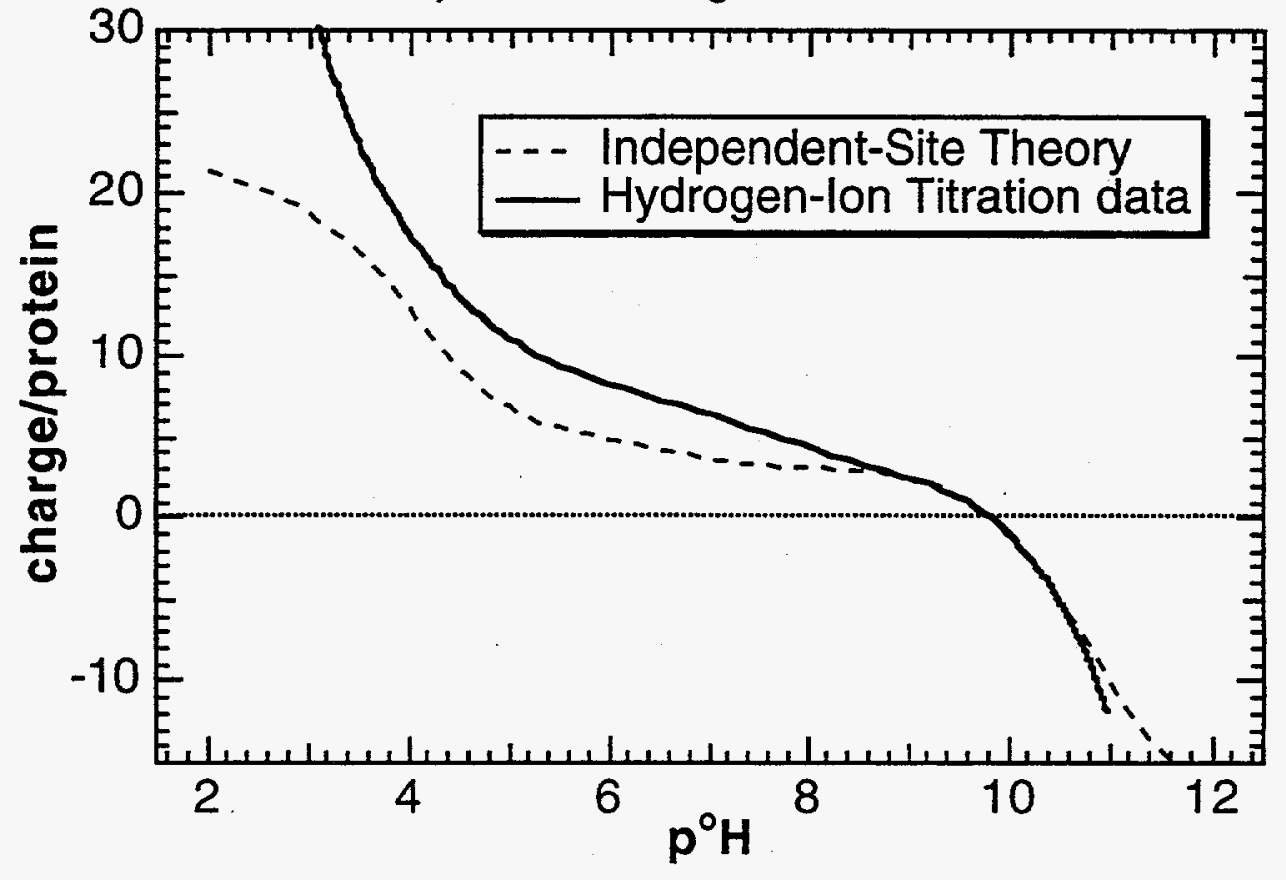

Figure 6: $\alpha$-Chymotrypsin hydrogen-ion titration comparison in

a) $1.0 \mathrm{M}$ IS and b) $3.0 \mathrm{M} \mathrm{IS}$ 


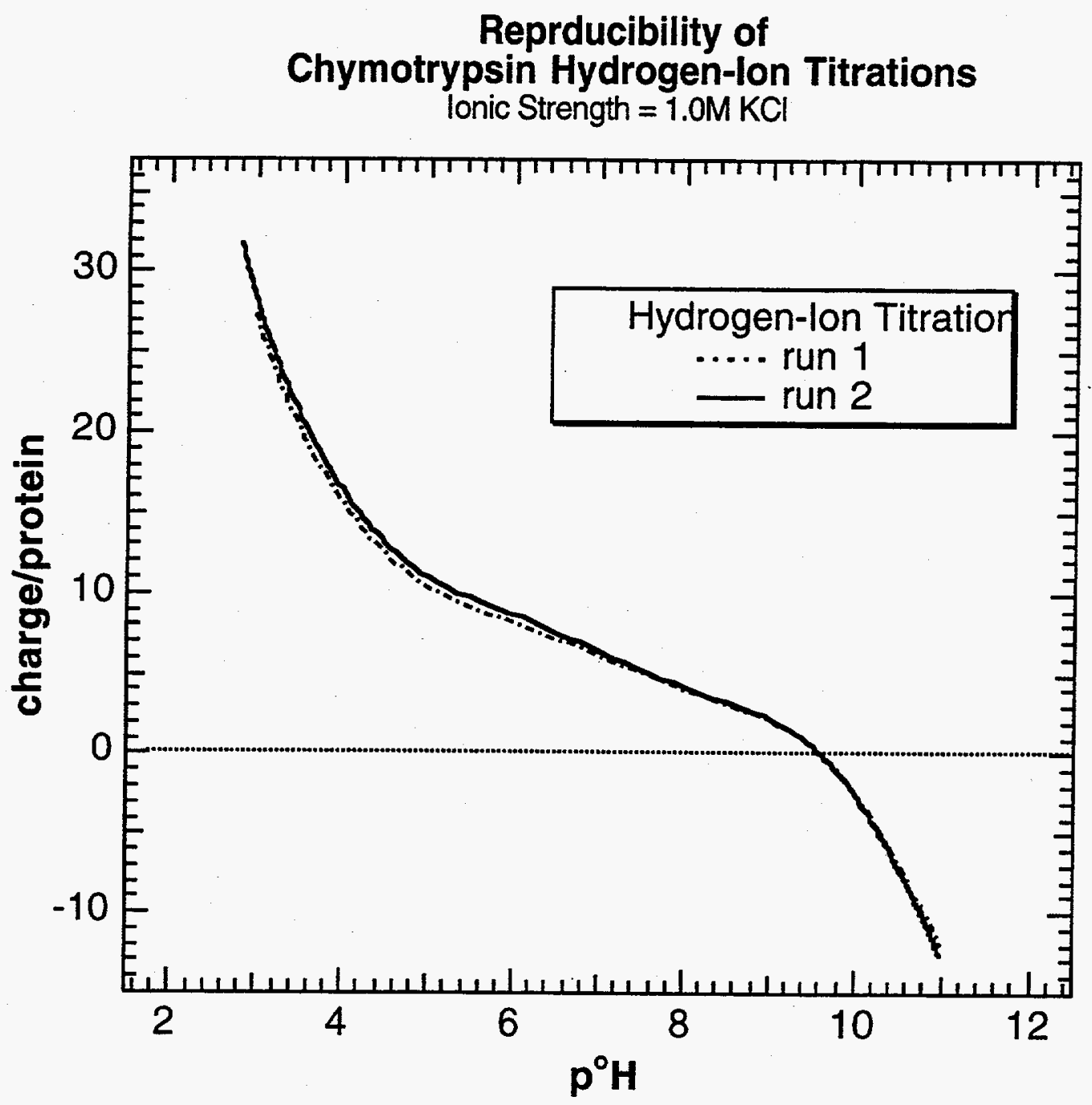

Figure 7: Reproducibility of chymotrypsin hydrogen-ion titration in IS=1.0 M KCl 


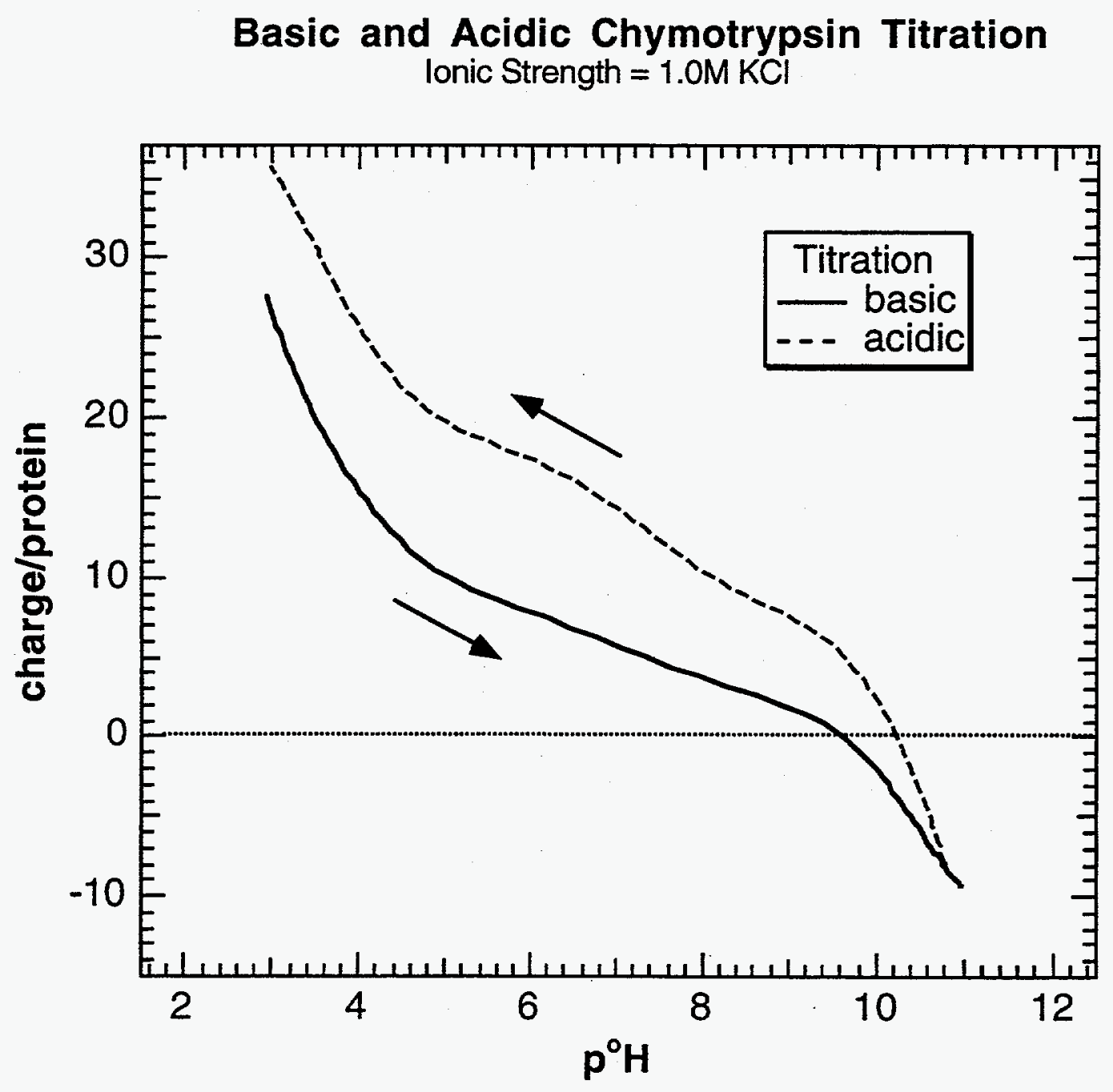

Figure 8: Basic and acidic titration of chymotrypsin in IS=1.0 M KCl 


\section{Conclusion}

In this work, an apparatus was constructed and a method developed to perform high precision titrations that measure the concentration of the hydrogen ions instead of their activity. The ligands were titrated efficiently by computerizing the experiment.

Titration results were obtained for 11 different amino acids dissolved in $\mathrm{KCl}$ at three separate ionic strengths $(0.1 \mathrm{M}, 1.0 \mathrm{M}$ and $3.0 \mathrm{M})$. Table 1 shows the $\mathrm{p}^{\circ} \mathrm{K}_{\mathrm{a}}$ values of the 13 titratable groups which are subsequently used for net charge vs. $\mathrm{pH}$ calculation for lysozyme and $\alpha$-chymotrypsin by the independent-site theory. In the majority of the titrations, the $\mathrm{p}^{\circ} \mathrm{K}_{\mathrm{a}}$ 's were reproducible to within 0.05 for each experiment. For the $0.1 \mathrm{M}$ $\mathrm{KCl}$ experiments, most of the $\mathrm{p}^{\circ} \mathrm{K}_{\mathrm{a}}$ 's differ from literature values by less than a few hundredths of a $\mathrm{pH}$ unit. Based on these arguments, we are confident that the experimental $\mathrm{p}^{\circ} \mathrm{K}_{\mathrm{a}}$ 's determined for the amino acid in IS $=1.0 \mathrm{M}$ and $\mathrm{IS}=3.0 \mathrm{M} \mathrm{KCl}$ are also accurate. The literature $\mathrm{p}^{\circ} \mathrm{K}_{\mathrm{a}}$ 's show a uniform trend with ionic strength that is matched by the experimentally determined $\mathrm{p}^{\circ} \mathrm{K}_{\mathrm{a}}$ 's. The values decrease initially with increasing ionic strength and reach a minimum near IS $=0.5 \mathrm{M}$, followed by a steady increase as ionic strength goes to $3.0 \mathrm{M}$. Because of this dependence, the $\mathrm{p}^{\mathrm{o}} \mathrm{K}_{\mathrm{a}}$ values are often nearly equal at $\mathrm{IS}=0.1 \mathrm{M}$ and $\mathrm{IS}=1.0 \mathrm{M}$. Appendix I contains all the measured $\mathrm{p}^{0} \mathrm{~K}_{\mathrm{a}}$ 's of the eleven amino acids, including the values for titratable groups that are not relevant for the protein net-charge calculations. These data can be used for further determination of the amino acid's $\mathrm{p}^{\mathrm{O}} \mathrm{K}_{\mathrm{a}}$ dependence on ionic strength.

The net charges of lysozyme and $\alpha$-chymotrypsin were calculated as a function of $\mathrm{pH}$ for each ionic strength using the experimental amino-acid $\mathrm{p}^{\circ} \mathrm{K}_{\mathrm{a}}$ 's and the IST. The IST assumes that all of the titratable groups of the protein are independent of each other and that their $\mathrm{p}^{\circ} \mathrm{K}_{\mathrm{a}}$ 's are equal to those in free amino-acid solution. To compare this theory with experimental results, we also performed hydrogen-ion titrations with lysozyme and $\alpha$ chymotrypsin at all three ionic strengths. For the low ionic-strength case $(0.1 \mathrm{M})$, the protein-titration data and the results obtained from the IST calculation agree reasonably well considering the large IST assumptions. Although the experimental and calculated titration curves show the same trends in high ionic strength $(1.0 \mathrm{M}, 3.0 \mathrm{M})$, an absolute comparison fails because of the uncertainties in the protein-titration data.

The IST is a first approximation for the calculation of protein net charge at high ionic strength. Improvements in the experimental titrations of proteins are required to asses 
accurately the validity of the IST. The amino-acid $\mathrm{p}^{\circ} \mathrm{K}_{\mathrm{a}}$ obtained here give a basis for further development of this theory. 


\section{A Amino-Acid Sequences of Lysozyme and $\alpha$-Chymotrypsin}

The amino acid sequences of lysozyme and $\alpha$-chymotrypsin are shown in Table 3 and Figure 9 respectively. These illustrations provide the type and number of all titratable groups contributing to the net charge calculation for each protein. These data are summarized in Table 4.

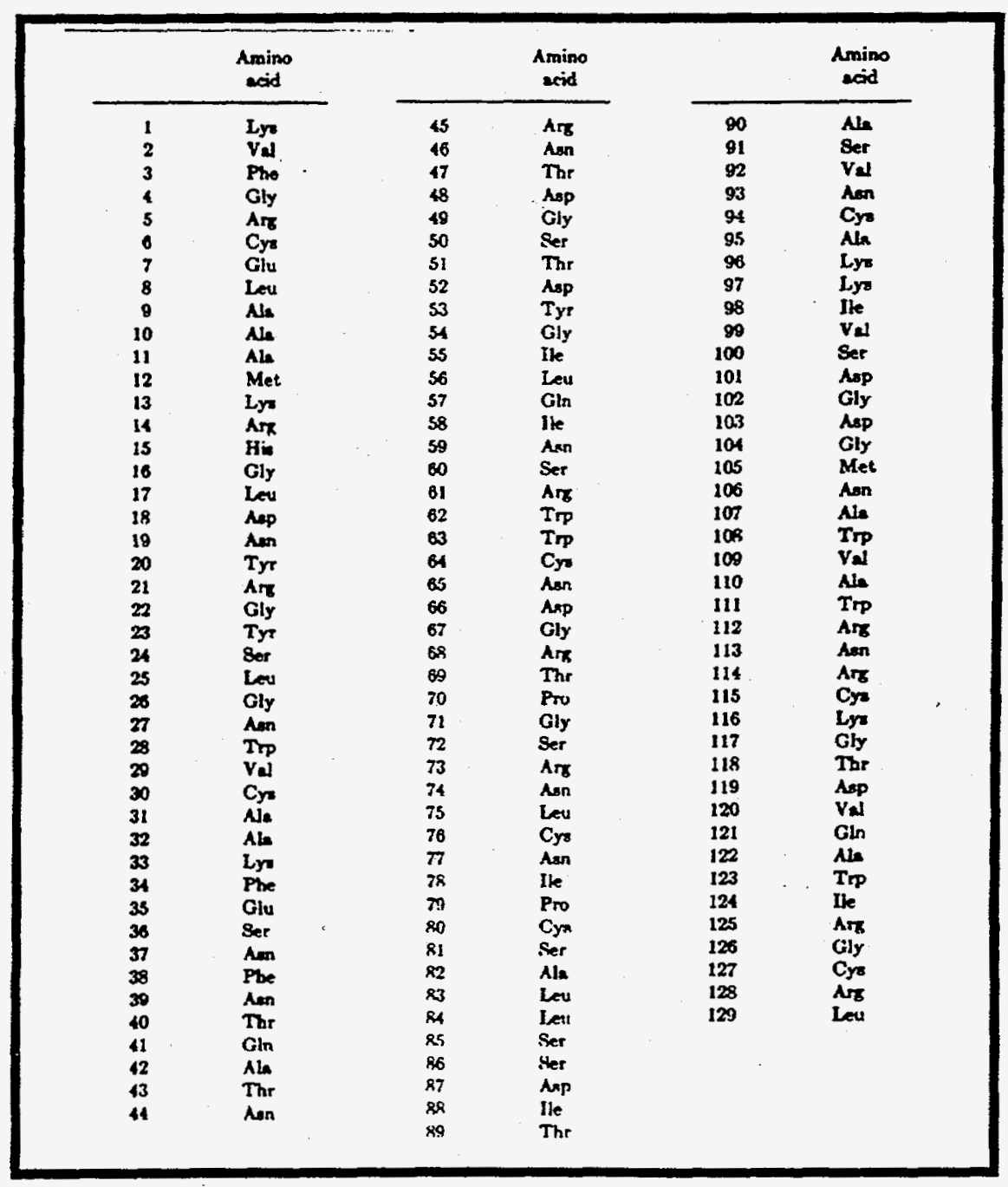

Table 3: Amino-acid sequence of lysozyme [14] 


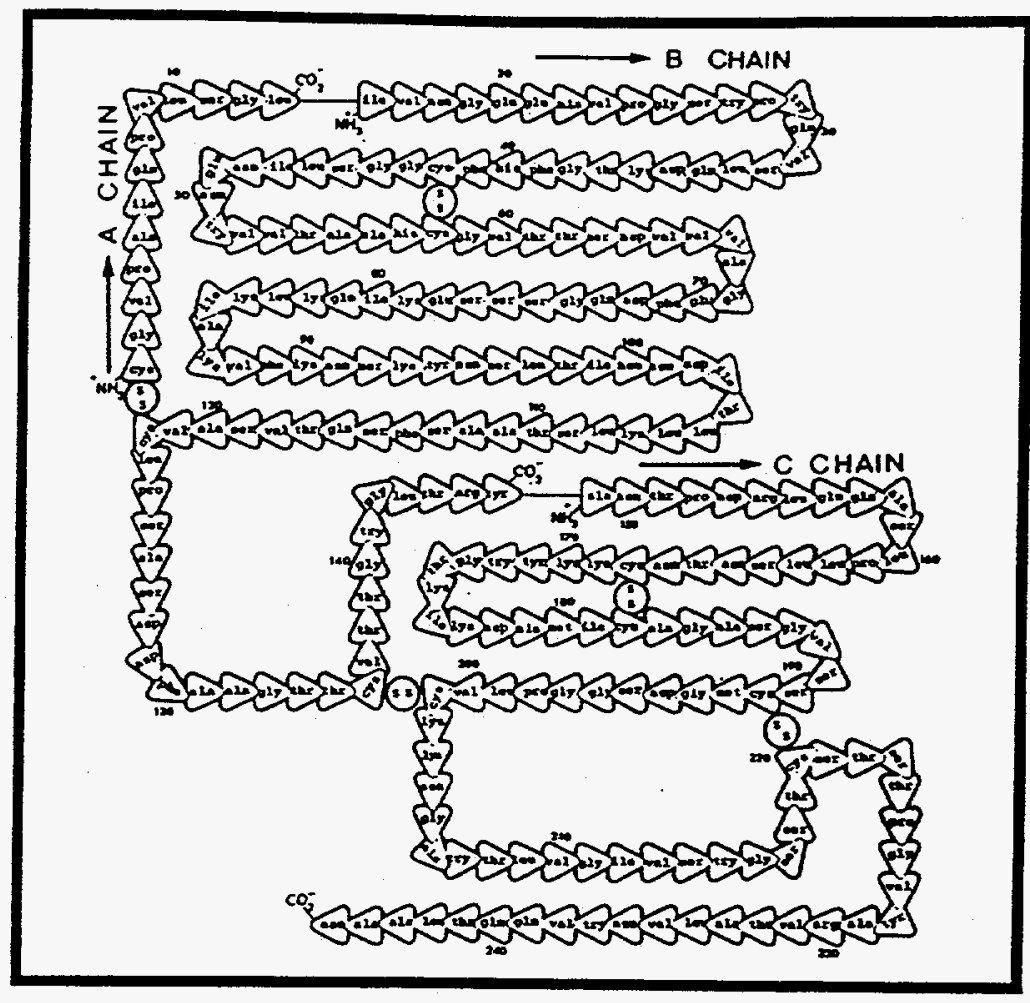

Figure 9: Amino-acid sequence of chymotrypsin [15]

\begin{tabular}{|c|c|c|c|}
\cline { 2 - 4 } \multicolumn{1}{c|}{} & Amino Acid & Chymotrypsin & Lysozyme \\
\hline Substituent & Arginine & 3 & 11 \\
& Aspartic Acid & 9 & 7 \\
Glutamic Acid & 5 & 2 \\
& Histidine & 2 & 1 \\
& Lysine & 14 & 6 \\
Carboxylic endgroup & Tyrosine & 4 & 3 \\
\cline { 1 - 4 } & Asparagine & 1 & 1 \\
\hline \multirow{2}{*}{ Amino Endgroups } & Leucine & 1 & \\
& Tyrosine & 1 & \\
\hline
\end{tabular}

Table 4: Titratable groups in lysozyme and chymotrypsin 


\section{B Electrode Calibration}

As derived in $\S 2$, for each ligand titration a calibration titration and subsequent regression of the electrode intercept and slope were performed in order to convert measured hydrogen ion activity $(E)$ into concentration $\left(\mathrm{p}^{\circ} \mathrm{H}\right)$. The parameters $E_{0}$ and $S$ are determined by fitting a line through the calibration-titration data points using a least squares Marquardt algorithm. Therefore these data must consist of a set of $\left(\mathrm{c}_{\mathrm{H}^{+}}, \mathrm{a}_{\mathrm{H}^{+}}\right)$points. The calibration titration yields only $\left(\mathrm{mL}_{\text {base added; }} \mathrm{aH}^{+}\right)$points. The hydrogen-ion concentration $\mathrm{p}^{\circ} \mathrm{H}$ can be calculated from the total solution volume, the volume of acidic titrant added before the start of the titration, the volume of basic titrant added ( $\mathrm{mL}_{\text {base added }}$ ) and the exact concentrations of acidic and basic titrant .

The calculation follows a strong acid/strong base titration in which a given amount of added $\mathrm{OH}^{-}$ions will consume a stoichiometric amount of $\mathrm{H}^{+}$ions present in solution [7]. Equation 29 and 30 describe the calculation for $\mathrm{p}^{\circ} \mathrm{H}$ below

$$
p^{o} H=-\log \left(c_{\text {acid }} \cdot \frac{V_{\text {acid }}}{V_{\text {total }}}-c_{\text {base }} \cdot \frac{V_{\text {base }}}{V_{\text {total }}}\right)
$$

and $\mathrm{p}^{\circ} \mathrm{H}$ above the equivalence point

$$
p^{o} H=p^{o} K_{W}+\log \left(c_{\text {base }} \cdot \frac{V_{\text {base }}}{V_{\text {total }}}-c_{\text {acid }} \cdot \frac{V_{\text {acid }}}{V_{\text {total }}}\right)
$$

From equation 30 , it follows that a $\mathrm{p}^{\circ} \mathrm{K}_{\mathrm{W}}$ is necessary to determine the $\mathrm{p}^{\circ} \mathrm{H}$ in the basic range. This $\mathrm{p}^{\circ} \mathrm{K}_{\mathrm{W}}$ is based on a $\mathrm{K}^{0} \mathrm{~W}$ defined as:

$$
K_{W}^{\dot{o}}=\frac{c_{H^{+}} \cdot c_{O H^{-}}}{c_{H_{2} O} \mathrm{O}}=\frac{K_{W}}{\frac{\gamma_{H^{+}} \cdot \gamma_{O H^{-}}}{\gamma_{H_{2} O}}}
$$

$\mathrm{K}^{\circ} \mathrm{W}$ is a constant for a certain ionic strength and temperature, as the water-dissociation constant $\mathrm{K}_{\mathrm{W}}$ depends only on the temperature and all activity coefficients are constant at a given high ionic strength of supporting electrolyte (see § 2). 
Although $\mathrm{K}^{\mathrm{O}} \mathrm{W}$ is constant for a certain ionic strength its value differs from the known $\mathrm{K}_{W}$ due to activity effects, and it must be fitted, as well. However, the $\mathrm{p}^{\circ} \mathrm{H}$ in the basic range will change with a changing $\mathrm{p}^{\circ} \mathrm{K}_{W}$. The Marquadt algorithm varies $\mathrm{p}^{\circ} \mathrm{KW}_{\mathrm{W}}$ based on an initial approximation until the best fit is reached [10].

When performing the regression of $S$ and $E_{0}$, the refinement program discards data points that differ more than a certain amount from the fitted function. Thus, a good fit quality of a calibration titration is represented by a low sum of squared residuals (SSR) and a high number of points used for the fit.

Figure 10 shows a calibration titration result in $\mathrm{IS}=0.1 \mathrm{M}$ containing the fitted parameters $\mathrm{E}_{0}$, slope $S$ and $\mathrm{p}^{\circ} \mathrm{K}_{\mathrm{W}}$ as well as the selected data points.

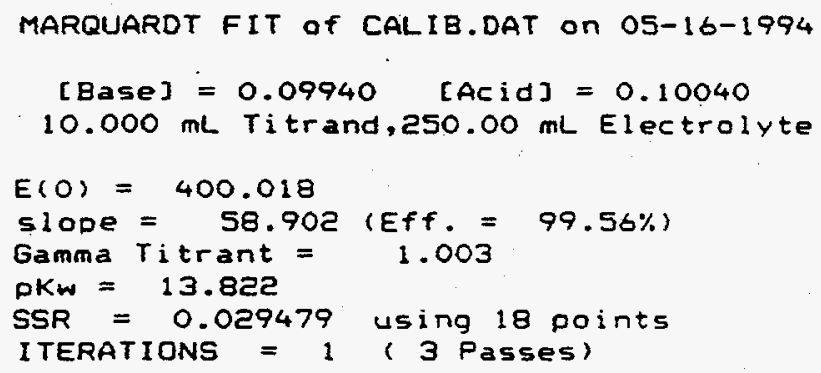

Figure 10: Refinement Printout of Calibration Titration 


\section{Details on Dosimat Pump Configuration and Operation}

\section{Operating units}

Injection switch: Controls the plunger in the syringe. Lifting the switch up injects a certain volume depending on working mode. Pushing down refills the syringe with titrant from the reservoir bottle.

Memory/Re-zero switch: Lifting the switch up stores the actual value of the digital counter in the memory. Pushing switch down re-zeros the digital counter.

Pump speed dial: Controls the injection speed of titrant (scale from 1 to 10 ).

Mode-selection switch: Controls the operating mode.

Digital meter: Displays injected volume, accurate to $0.01 \mathrm{~mL}$.

Operating modes (explained in symbols on top of the Dosimat)

Mode 1: Titrant will be added at determined pump speed if the injection switch is lifted.

Mode 2: Every 5 lifts of the injection switch cause $0.01 \mathrm{~mL}$ titrant to be added.

Mode 3: Every lift of the injection switch will add the titrant aliquot stored in the memory.

Mode 4: Same as mode 3 except syringe refills after each injection.

Mode 7: Allows entry of desired aliquot volume into resident memory by manipulation of the injection switch.

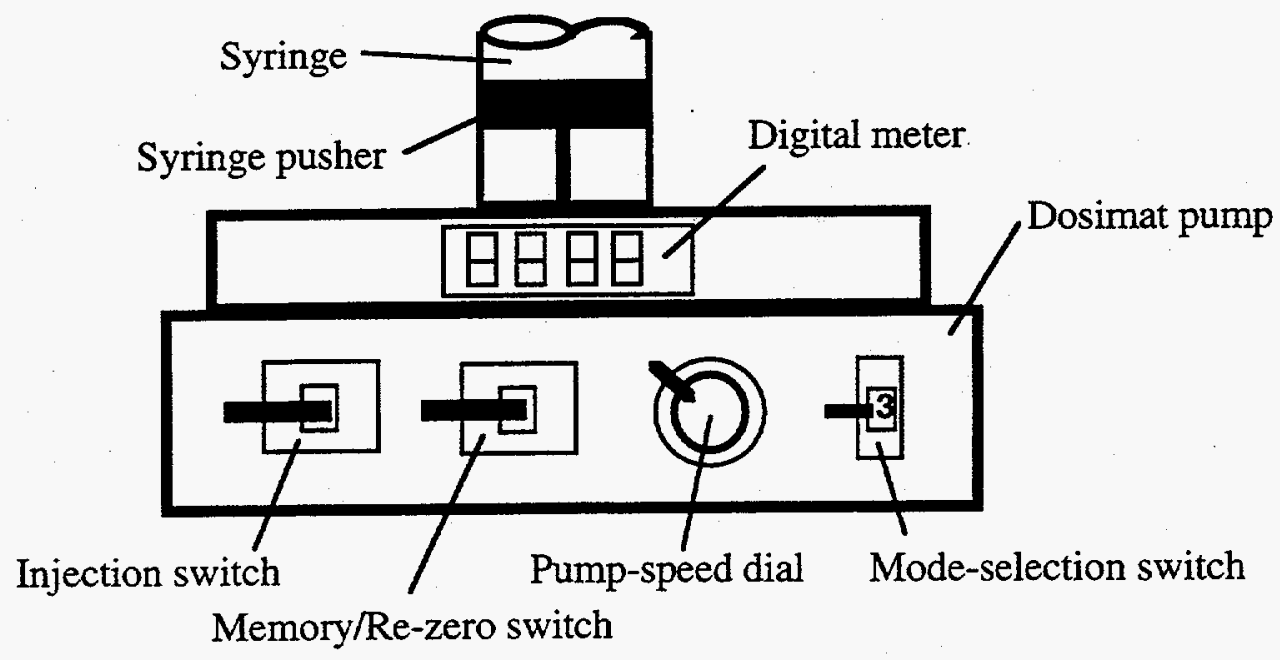

Figure 11: Dosimat Pump 


\section{Lid Construction}

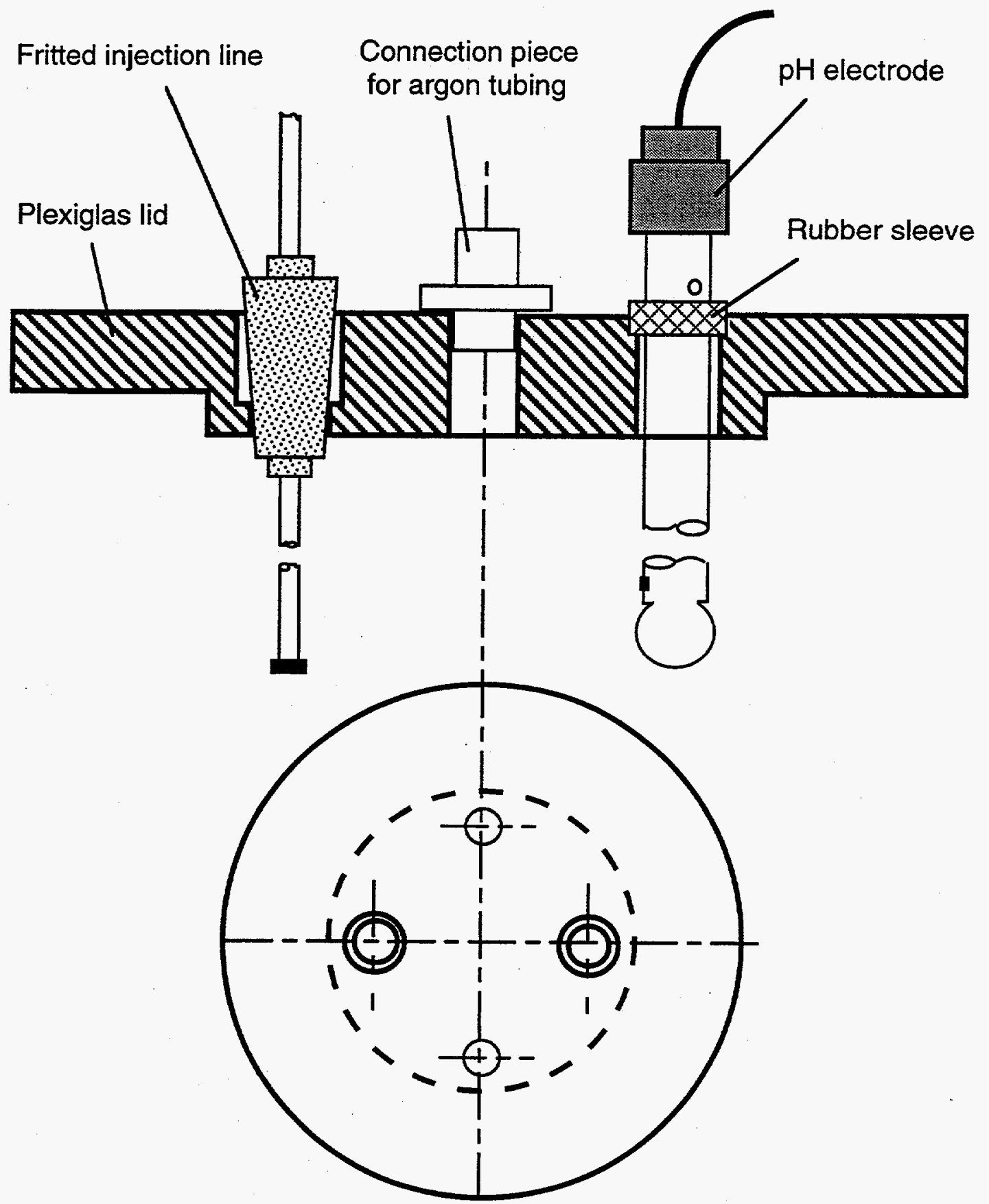

Reduced view of lid (from above)

Figure 12: Lid-construction drawing 


\section{E Details of Apparatus Troubleshooting}

In the process of constructing and automating the titration apparatus, several problems were encountered along the way. The following is a list of these problems and the changes that were made to correct them. These are important for future operators in order to minimize experimental errors and time spent trouble shooting.

(1) For $\mathrm{mV}$ inputs to the A-to-D board greater than $\pm 200 \mathrm{mV}$, the output from the board lost correlation with the $\mathrm{mV}$ inputs and the response became random. Proper grounding of the A-to-D board remedied this problem, allowing signals of greater than $\pm 200 \mathrm{mV}$ to be measured accurately [16].

(2) The 12-bit resolution of the A-to-D board made single measurements of $\mathrm{mV}$ response from the $\mathrm{pH}$ electrode inaccurate [16]. Therefore, it was decided to make each $\mathrm{p}^{\circ} \mathrm{H}$ point measured consist of an average of 300 separate $\mathrm{mV}$ readings, collected over 3 seconds with a frequency of 100 readings per second.

(3) An external digital voltmeter was installed in parallel with the A-to-D board to provide confirmation of the stability of the $\mathrm{mV}$ output from the $\mathrm{pH}$ electrode and an independent check on the performance of the A-to-D board.

(4) It was found that a certain type of Dosimat syringe was constructed in a manner that allowed a potential gradient to be established between the Dosimat itself and the $\mathrm{pH}$ electrode though the titrant solution. This introduced an error of up to $\pm 3 \mathrm{mV}$ in our $\mathrm{p}^{\mathrm{oH}}$ readings corresponding to a $\Delta \mathrm{p}^{\circ} \mathrm{H}$ of 0.05 . A different syringe with more extensive insulation was then employed, eliminating the external voltage drop.

(5) Originally it had been planned to conduct amino-acid and protein titrations in $\left(\mathrm{NH}_{4}\right)_{2} \mathrm{SO}_{4}$ solutions. However, the $\mathrm{pH}$ electrode calibrating must be conducted in solutions of strong acid and strong base which have no secondary hydrogen-ion equilibria in order for the program CAL-ANAL to determine electrode slope and intercept accurately. Therefore it was decided to study amino acid and proteins in solutions of $\mathrm{KCl}$ instead. 


\section{F Program Flow Sheet for CAL-TITR and TITRATE}

Figure 13 is a flow sheet for the programs CAL-TITR and TITRATE. Before any titrant is added, the initial $\mathrm{p}^{\circ} \mathrm{H}$ of the titrant solution is measured. This is done by averaging 300 separate $\mathrm{mV}$ readings taken at a frequency of 100 readings per second. The $\mathrm{mV}$ readings are converted to $\mathrm{p}^{\circ} \mathrm{H}$ using the appropriate values of electrode slope and intercept from CALIB.PAR. The electrode slope and intercept will be the generic default values in the case of CAL-TITR (electrode-calibration titration; slope $=60 \mathrm{mV} / \mathrm{pH}, \mathrm{E}_{0}=400 \mathrm{mV}$ ). In the case of TITRATE (titration of ligand after electrode has been calibrated), they will be equal to the fit values calculated by CAL-ANAL. Four of these converted $\mathrm{p}^{\circ} \mathrm{H}$ measurements (each composed of the average of $300 \mathrm{mV}$ readings) are made. If the average of the first three is within $0.01 \mathrm{pH}$ units of the last, the $\mathrm{p}^{\mathrm{o}} \mathrm{H}$ is considered to be in equilibrium and the $\mathrm{p}^{\circ} \mathrm{H}$ point is written to a data file along with the volume of titrant added (zero in the case of the initial $\mathrm{p}^{\circ} \mathrm{H}$ measurement when no titrant has been added yet). However, if this convergence criteria is not met, the $\mathrm{p}^{\circ} \mathrm{H}$ is considered to be not yet equilibrated, and the program collects another $\mathrm{p}^{\mathrm{O}} \mathrm{H}$ measurement (again composed of the average of $300 \mathrm{mV}$ readings taken over 3 seconds) and tests for convergence with the four most recent $\mathrm{p}^{\circ} \mathrm{H}$ readings. The process of convergence testing proceeds for up to 9 separate $\mathrm{p}^{\circ} \mathrm{H}$ measurements, after which if convergence has not been archived, the average of the last $4 \mathrm{p}^{\circ} \mathrm{H}$ measurements is taken as the value of $\mathrm{p}^{\circ} \mathrm{H}$ and is written to the data file*. After the most recent $\mathrm{p}^{\mathrm{OH}}$ and volume-added titration point is written to the file, the program checks to see if the titration endpoint has been reached (final volume for CAL-TITR; final $\mathrm{p}^{\mathrm{oH}}$ for TITRATE). If not, then an aliquot of titrant is injected, the defined delay time elapses, and the program again begins measuring and averaging the new $\mathrm{p}^{\circ} \mathrm{H}$. When the titration endpoint is reached, the program will terminate.

\footnotetext{
*In all our calibration and ligand titrations, the hydrogen-ion dissociation reactants equilibrated very quickly, and convergence was usually achieved with the first four $\mathrm{p}^{\circ} \mathrm{H}$ measurements.
} 


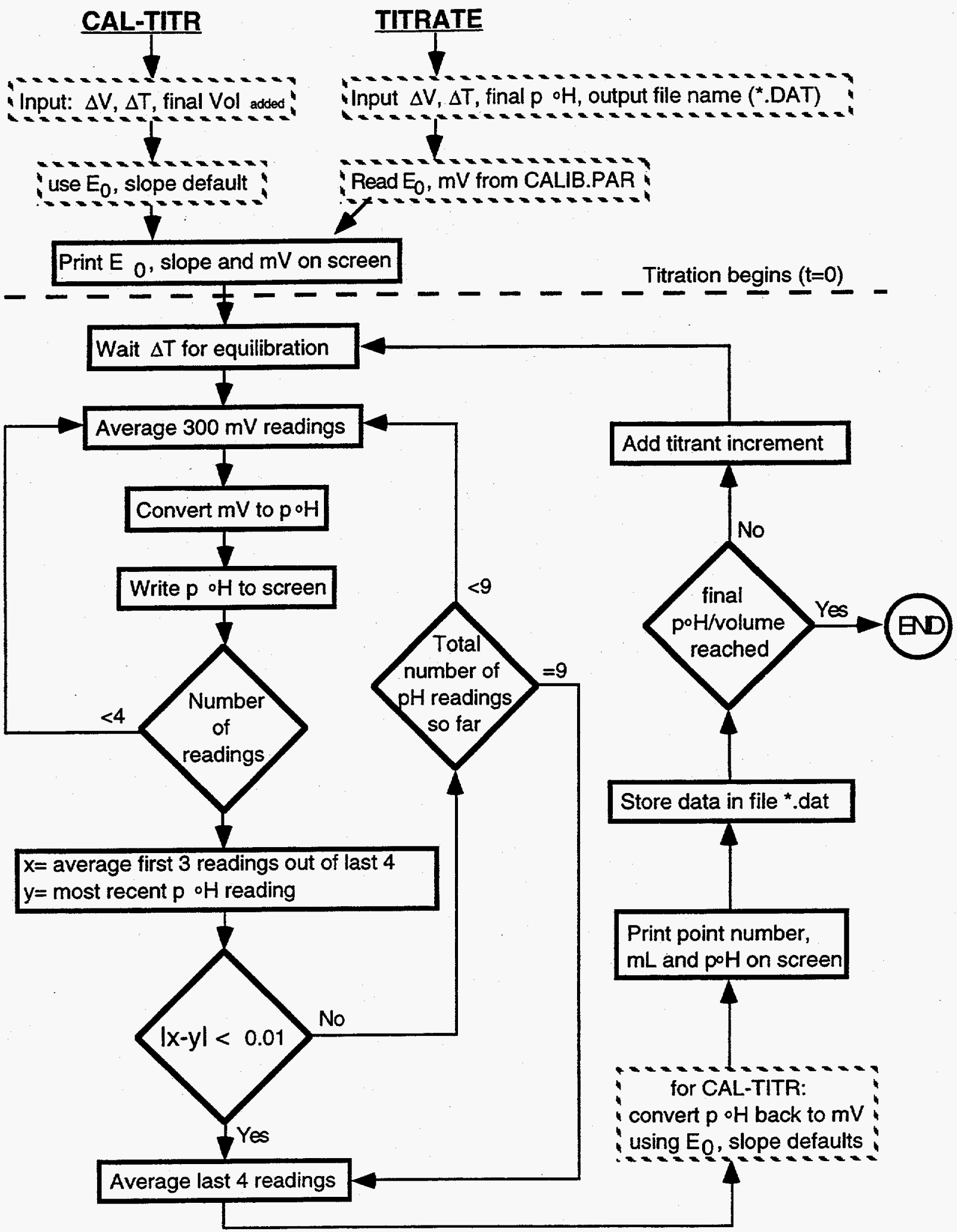

Figure 13: Program Flow Sheet for CAL-TITR and TITRATE 


\section{G Setup and Operation of BETA90}

The potentiometric data refinement described in this chapter can only be used for amino-acid titration data, as the maximum number of $\mathrm{pK}_{\mathrm{a}}$ 's in BETA90 is limited to 20 . The refinement of amino-acid $\mathrm{p}^{\circ} \mathrm{K}_{\mathrm{a}}$ 's takes two steps: the creating of an BETA90 input file with SETUPBTA and the modification of some values within this file to improve the goodness of fit (G.O.F.).

\section{G.1 SETUPBTA Inputs}

The program BETA90 regresses amino-acid $\mathrm{p}^{\circ} \mathrm{K}_{\mathrm{a}}$ 's from experimental titration data. BETA90 requires input of all the relevant information to perform $\mathrm{p}^{\circ} \mathrm{K}_{\mathrm{a}}$ fitting in very a specific format. The program SETUPBTA is executed prior to BETA90 [10]; it assembles all the relevant information and creates a file called *.INP with the proper format for BETA90. An exact replica of a SETUPBTA input screen is shown below, with explanation of all information prompts.

Input Prompt

- Input titration data file name

- File name for BETA input file

- Run descriptor

- \# of cycles (NC)

- \# of formation constants to be refined (NV)

- \# of reacting components (NX)

- Analytical derivatives

- Computer weighting scheme

- Total \# of formation constants
Correct Response

*.DAT

*.INP

*.INP

9

2 or 3

2

enter

enter

2 or 3

\section{Explanation}

header of summary

number of $\mathrm{p}^{\circ} \mathrm{K}_{\mathrm{a}}$ 's to be regressed (should do all $\mathrm{p}^{\mathrm{o}} \mathrm{K}_{\mathrm{a}}{ }^{\prime} \mathrm{s}$ ) amino acid and hydrogen ion use yes default use yes default total number of $\mathrm{p}^{\circ} \mathrm{K}_{a}$ 's in amino acid 
- Enter key integer

guesses for $\mathrm{pKa}$ 's in an additive

form starting with highest one

Example for an amino acid

1

with $3 \mathrm{pKa}$ 's

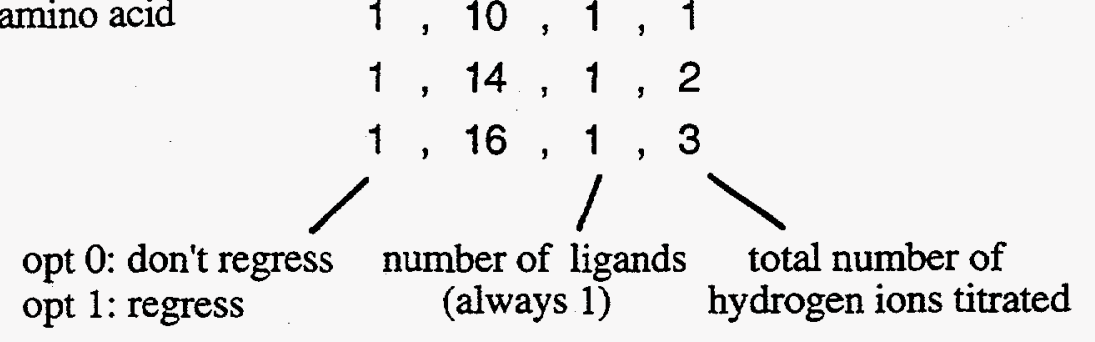

- intercept

enter

use 0 default

- slope

enter

use 1 default

- $\mathrm{pKw}$

$\mathrm{p}^{\mathrm{o}} \mathrm{Kw}$

from calibration titration

At this point, SETUPBTA reads in the experimental data from *.DAT file

- enter \# of protonated sites (NH)

1 or 2

\# of protonated sites on amino acid upon dissolving in $\mathrm{KCl}$;

e.g. $g l u=2$, his $=1$

- analytical millimoles of ligand

*the exact values

- concentration of titre (base is -)

$-0.1$

- millimoles added acid at beginning

2.000

$*$ from the

- initial volume at beginning of titration (mL)

270

*titration sheet

$250+$ Volume titrant added to reach starting $\mathrm{p}^{\mathrm{OH}}$

- initial guess for $\mathrm{pL}$

enter

use default

- sigma of pH meter

enter

use default

- sigma of buret

enter

use default

OK. Your BETA input file is setup. It is named *.INP

\section{G.2 Refining Amino-Acid $\mathrm{pK}_{\mathrm{a}}$ 's with BETA90}

With the properly-configured *.INP file as input, BETA90 will fit $\mathrm{p}^{\circ} \mathrm{K}_{\mathrm{a}}$ 's from the experimental titration data. After the program has terminated and written the results to the files *.SUM and PLOT.O\&C, it is important to determine the quality of the $\mathrm{p}^{\circ} \mathrm{K}_{\mathrm{a}}$ fits performed. This is done by checking several quantities. 
A first step is to issue the command "see". This creates a plot of measured $\mathrm{p}^{\circ} \mathrm{H}$, calculated $\mathrm{p}^{\circ} \mathrm{H}$ (based on $\mathrm{p}^{\circ} \mathrm{K}_{a}$ 's found by BETA90) and the difference between measured and calculated poH's against the net charge of the amino acid (which is also calculated from the fit $\left.\mathrm{p}^{\circ} \mathrm{K}_{\mathrm{a}}{ }^{\prime} \mathrm{s}\right)$. It is generally observed that the $\Delta \mathrm{p}^{\circ} \mathrm{H}$ has a spike near the equivalence point in the ligand titration curve. This, is the point where the $\mathrm{p}^{\circ} \mathrm{H}$ changes most rapidly with addition of titrant. Thus there are fewer data at this point in the titration than at the $\mathrm{p}^{\circ} \mathrm{H}$ extremes, decreasing the sensitivity of the fit performed by BETA90 near the equivalence point; hence, we see a maximum in the $\Delta \mathrm{p}^{\circ} \mathrm{H}$ curve here. A smaller $\Delta \mathrm{p}^{\circ} \mathrm{H}$ spike indicates a better fit.

Another equally important indicator of the $\mathrm{p}^{\mathrm{o}} \mathrm{K}_{\mathrm{a}}$ fit quality is the G.O.F. parameter contained in the *.SUM file. This parameter is related to the overall error in the $\mathrm{p}^{\circ} \mathrm{K}_{\mathrm{a}}$ fitting procedure; a smaller G.O.F. indicates a more accurate fit. A G.O.F. of 6 is considered the maximum allowable for a good fit.

It is possible to minimize the G.O.F. and the $\Delta \mathrm{p}^{\circ} \mathrm{H}$ spike for a given titration by adjusting very slightly certain of the parameters contained in the *.INP file [10]. This is done by invoking the screen editor, taking care to preserve the exact input format required for BETA90 to recognize all the contents of the *.INP file.

Experience has shown that manual variation of 3 parameters - mass of ligand, amount of acid initially added to the titration vessel, and fit $\mathrm{p}^{\circ} \mathrm{K}_{\mathrm{W}}$ - by less than $1 \%$ each can improve the G.O.F. dramatically for a given set of titration data [10]. Variation in the amount of ligand results in general improvement of G.O.F.. Variation of the amount of initial acid reduces the $\Delta \mathrm{p}^{\circ} \mathrm{H}$ spike near the equivalence point. Deviations in this curve in basic regime are diminished by varying $\Delta \mathrm{p}^{\mathrm{o}} \mathrm{H}$. It is important to check the G.O.F. and view the contents of the PLOT.O\&C file via "see" after making each change in order to determine whether overall improvement has resulted.

While this parameter variation may often result in improvement of fit quality for the calculated curve, it does not produce more than $0.2 \mathrm{pH}$ units change in fit $\mathrm{p}^{0} \mathrm{~K}_{\mathrm{a}}$ 's. 


\section{H Experimental Procedure for Titration}

The aim of this chapter is to give guidance for conducting titration experiments,

collecting all necessary experimental data and especially creating the $\mathrm{mL}_{\text {added }} / \mathrm{p}^{\circ} \mathrm{H}$-output file describing this titration run. This *.DAT file is the basis for discussion of the results. In the case of protein experiments it can be converted to a net-charge vs. $\mathrm{p}^{\mathrm{O}} \mathrm{H}$-file (compare $\S 4$ Discussion) or in the case of amino-acid experiments it is needed for the subsequent $\mathrm{p}^{0} \mathrm{~K}_{\mathrm{a}}$-refinement.

\section{1) Solution Preparations}

Acid/Base Titrant: In order to guarantee a sufficient number of titration data points to perform accurate $\mathrm{p}^{0} \mathrm{~K}_{\mathrm{a}}$ fitting, it was decided to set the $\mathrm{HCl} / \mathrm{KOH}$ concentration in the acidic/basic titrant to $0.1 \mathrm{~N}$. Therefore, in our high IS titrations, the balance of the ionic strength was made up by adding of $\mathrm{KCl}$ to the titrant solutions.

- Weigh the amount of $\mathrm{KCl}$ necessary to reach the desired ionic strength

- Dissolve salt in $-250 \mathrm{~mL}$ nanopure water in a clean $2 \mathrm{~L}$ volumetric flask

- Add the volume of $1.00 \mathrm{~N} \mathrm{HCl}$ or KOH stock-solution (Fisher Chemical SA48-4 and SP208-500) necessary to create a $0.1 \mathrm{~N}$ solution

- Top off the volumetric flask with nanopure water, then mix thoroughly with magnetic stirrer

- Disperse titrant into appropriate reservoir bottle; seal bottle and blanket with argon

\section{Potassium Hydrogen Phthalate (KHP) Solution:}

- Weigh $0.2 \mathrm{mg} \mathrm{KHP}$ in weighing dish on analytical balance; record exact weight to 5 decimal places

- Dissolve $\mathrm{KHP}$ in $~ 100 \mathrm{~mL}$ nanopure water in a clean $250 \mathrm{~mL}$ volumetric flask, extreme care must be exercised to make sure all KHP is transferred into the volumetric flask. Accuracy of the $\mathrm{HCl} / \mathrm{KOH}$ concentration measurement depends strongly on this step 
- Weigh the amount of $\mathrm{KCl}$ necessary to achieve the desired solution ionic strength • Dissolve $\mathrm{KCl}$ in $\mathrm{KHP}$ solution, top off the volumetric flask with nanopure water

KCl Solution: (used in $\mathrm{HCl} / \mathrm{KOH}$ titrations for $\mathrm{pH}$ electrode calibration)

- Weigh the amount of $\mathrm{KCl}$ necessary to achieve the desired ionic strength

- In a clean $1 \mathrm{~L}$ volumetric flask dissolve $\mathrm{KCl}$ in nanopure water, top off volumetric flask

\section{Titration Solution with Amino Acid as Ligand:}

- Weigh the appropriate amount of amino acid determined by solubility considerations directly into a clean, dry $250 \mathrm{~mL}$ volumetric flask on a analytical balance; record exact weigh to 4 decimal places

- Weigh the amount of $\mathrm{KCl}$ necessary to achieve the desired ionic strength into a separate weigh dish

- Rinse $\mathrm{KCl}$ into the $250 \mathrm{~mL}$ volumetric flask containing amino acid; dissolve contents of flask in nanopure water; top off volumetric flask

\section{Titration Solution with Protein as Ligand:}

- Weigh the determined amount of protein into a beaker on a tared analytical balance

- Add enough $\mathrm{KCl}$ solution of the desired ionic strength described above to the beaker to dissolve the powdered protein

- Transfer protein solution to a clean and dry $250 \mathrm{~mL}$ volumetric flask; top off volumetric flask with $\mathrm{KCl}$ solution; mix thoroughly

- Reserve $10 \mathrm{~mL}$ of the protein solution for later UV spectrophotometric measurements of protein concentration 


\section{2) Titrant Standardization}

The following is a procedural outline for the measurement of exact concentrations of $\mathrm{HCl}$ and $\mathrm{KOH}$ in the acidic and basic titrant, respectively. Phenolphthalein is used as a $\mathrm{pH}$ indicator.

\section{Base Titrant Standardization (KOH):}

- Activate argon supply to titrant-reservoir bottles

- Turn on the temperature bath and wait until the desired temperature is reached

- Switch Dosimat to 'mode 1' to allow manual titrant dispensing (see Appendix C)

- Place syringe unit with basic reservoir bottle in the Dosimat and flush any air bubbles from the fritted injection line by dispensing about $3 \mathrm{~mL}$ titrant into a beaker on pump speed 6 or greater.

- Place the potassium hydrogen phthalate (KHP) $\mathrm{KCl}$ solution into the titration vessel

- Add 10 drops of a $0.15 \%$ phenolphthalein solution in ethanol; stir magnetically

- Rinse the basic titrant fritted injection line and place it in the vessel, securing it with a clamp

- Add carefully, beginning on pump speed 5 and slowing down to speed 1 , until the $\mathrm{pH}$ endpoint is reached. The endpoint is defined as the first pink color that does not disappear after one minute

- Record the volume of basic titrant required to reach the $\mathrm{pH}$ endpoint. This volume is necessary in order to calculate the $\mathrm{KOH}$ concentration, using the following equation:

$$
\begin{aligned}
c_{\text {base }}=\frac{m_{K H P}}{M_{K H P}} / V_{\text {base }} \\
\text { where } \mathrm{m}_{\mathrm{KHP}}=\mathrm{g} \mathrm{KHP} \\
\mathrm{M}_{\mathrm{KHP}}=\text { molecular weight of } \mathrm{KHP},=204.22 \mathrm{~g} / \mathrm{mol} \\
\text { Vbase }=\text { measured volume of basic titrant added }
\end{aligned}
$$

- Discard titration solution, rinse vessel and refill Dosimat dispenser syringe

- Repeat the above steps at least 2 times or until a reproducible $\mathrm{KOH}$ concentration is measured 


\section{Acid Standardization (HCl):}

- Place $250 \mathrm{~mL} \mathrm{KCl}$ solution of desired ionic strength in titration vessel; add about 10 drops of a $0.15 \%$ phenolphthalein solution in ethanol; stir magnetically

- Place syringe unit with acid reservoir bottle in the Dosimat and flush all air bubbles from the fritted injection line

- Rinse the fritted injection line and place it in the vessel, securing it with a clamp

- Add exact $15 \mathrm{~mL}$ of acid with the pump in programming 'mode 4' (see Appendix C)

- Place syringe unit with basic reservoir bottle in the Dosimat and flush all air bubbles from the fritted injection line

- Perform a neutralization titration as described in the basic titrant-standardization section above

- Record the volume of basic titrant required to reach the $\mathrm{pH}$ endpoint. Calculate the acid concentration using the following equation:

$$
c_{\text {acid }}=\left(\mathrm{c}_{\text {base }} \cdot \mathrm{V}_{\text {base }}\right) / V_{\text {acid }}
$$

- Repeat the above steps at least 2 times or until reproducibility in $c_{\text {acid }}$ is demonstrated

\section{3) pH Electrode Calibration}

- Activate argon supply to the titrant-reservoir bottles

- Turn on the temperature bath and wait until the desired temperature is reached

- Carefully rinse the titration vessel and stir bar with nanopure water

- Place the acid titrant syringe unit into the Dosimat and flush all air bubbles from the injection line using pump 'mode 1 '

- Place $250 \mathrm{~mL}$ of $\mathrm{KCl}$ solution, of the same ionic strength as the subsequent potentiometric titration, in the titration vessel; stir magnetically

- Seal vessel with lid and blanket with argon

- Insert $\mathrm{pH}$ electrode into the titration vessel through the proper hole in the lid. Make sure rubber ring around the top of electrode makes a tight seal with the lid. Switch 
$\mathrm{pH}$ meter to $\mathrm{mV}$ mode. Note: always switch the $\mathrm{pH}$ meter to 'standby' when removing electrode from solution

- Dispense $10 \mathrm{~mL}$ of acid titrant into the vessel using the Dosimat in 'mode 4'

- Exchange the acidic titrant syringe unit with the basic titrant syringe unit. When the basic titrant syringe unit is secure, flush all air bubbles from the injection line (mode1)

- Allow 5 minutes for solution temperature and electrode response to equilibrate

- Program Dosimat to add basic titrant aliquots of $0.7 \mathrm{~mL}$ in 'mode 7', then switch to 'mode 3' (see Appendix C)

- Run calibration-titration program CAL-TITR

- When calibration titration is complete ( 20 minutes) place $\mathrm{pH}$ meter on 'standby' and remove electrode from the vessel immediately, rinse the electrode and place it in the storage buffer

- Run program CAL-ANAL to analyze electrode-calibration data. Record calibration parameters in the electrode logbook. Attach printouts of calibration data and results for record keeping (see figure 10 in Appendix B)

\section{Basic Ligand Titration ( $\mathrm{KOH})$}

- Rinse and dry the titration vessel

- Place $250 \mathrm{~mL}$ of amino acid or protein solution in the vessel

- Flush all titrant injection lines

- Seal vessel with lid and blanket with argon

- Rinse $\mathrm{pH}$ electrode and place it into vessel as described above. Set $\mathrm{pH}$ meter on $\mathrm{mV}$ mode

- Begin gentle stirring. Allow 5 minutes for the solution temperature and electrode response to equilibrate and for argon blanket to establish

- Add the determined volume of acid using 'mode 1' or ' 4 ' until poH equals 2.5

- Program the basic titrant increment to be added in 'mode 7'; switch to 'mode 3'

- Run titration program TITRATE

- Record all relevant information on the titration information sheet

- When titration is complete, set $\mathrm{pH}$ meter to 'standby', remove and rinse $\mathrm{pH}$ electrode, close electrode reference solution fill-cap and place in storage solution.

- Make a back-up copy of *.DAT on floppy for archiving and transfer to computer with program BETA90 
For protein titrations it is possible to reduce the cost of a titration by preparing 50 $\mathrm{mL}$ of protein solution instead of $250 \mathrm{~mL}$. After the electrode-calibration titration, place this $50 \mathrm{~L}$ of protein solution in a $150 \mathrm{~mL}$ beaker on a platform inside the titration vessel. For temperature control, fill the titration vessel with water so that the sides of the beaker containing the protein solution are covered.

For best $\mathrm{pH}$ electrode response and accurate measurements it is recommended to alternate the two $\mathrm{pH}$ electrodes in use. Furthermore, an exchange of the $\mathrm{pH}$ electrode filling solution every 5 titration experiments contributes to a faster recover of the $\mathrm{pH}$ electrode after a ligand titration. 
Aminoacid Carbox.acid Ammon.group Substituent

\begin{tabular}{|l|l|l|l|l|}
\hline Ala & 2.361 & 9.849 & & 3.238 \\
\hline & 2.353 & 9.875 & & 3.858 \\
\hline
\end{tabular}

\begin{tabular}{|l|l|l|l|l|}
\hline Arg & 2.146 & 9.163 & 13.424 & 1.935 \\
\hline 2.058 & 9.072 & 12.676 & 3.050 \\
\hline 2.047 & 9.042 & 12.872 & 1.977 \\
\hline
\end{tabular}

\begin{tabular}{|l|l|l|l|l|}
\hline Asn & 2.175 & 8.731 & & 0.878 \\
\hline 2.191 & 8.729 & & 0.886 \\
\hline & & & \\
\hline
\end{tabular}

\begin{tabular}{|l|l|l|l|l|}
\hline Asp & 2.000 & 9.758 & 3.727 & 1.781 \\
\hline 1.992 & 9.685 & 3.719 & 1.884 \\
\hline & & & \\
\hline
\end{tabular}

\begin{tabular}{|l|l|l|l|l|}
\hline Cys & 2.001 & 10.247 & 8.194 & 1.823 \\
\hline 1.924 & 10.440 & 8.254 & 1.218 \\
\hline 1.938 & 10.404 & 8.233 & 1.770 \\
\hline
\end{tabular}

\begin{tabular}{|l|l|l|l|l|}
\hline Glu & 2.238 & 9.647 & 4.184 & 2.236 \\
\hline \multirow{2}{*}{2.206} & 9.638 & 4.161 & 2.070 \\
\hline & & & \\
\hline
\end{tabular}

Aminoacid Carbox.acid Ammon.group Substituent G.O.F.

\begin{tabular}{|l|l|l|l|l|}
\hline His & 1.731 & 9.160 & 6.062 & 2.99 \\
\hline & 1.698 & 9.143 & 6.059 & 2.436 \\
\hline & & & & \\
\hline
\end{tabular}

\begin{tabular}{|l|l|l|l|l|}
\hline$l e$ & 2.330 & 9.632 & & 2.492 \\
\hline 2.328 & 9.645 & & 1.553 \\
\hline & & & & \\
\hline
\end{tabular}

\begin{tabular}{|l|l|l|l|l|}
\hline Leu & 2.332 & 9.651 & & 1.764 \\
\hline 2.318 & 9.631 & & 1.303 \\
\hline & & & \\
\hline
\end{tabular}

\begin{tabular}{|l|l|l|l|l|}
\hline Lys & 2.106 & 9.216 & 10.826 & 5.298 \\
\hline 2.089 & 9.205 & 10.788 & 1.677 \\
\hline & & & \\
\hline
\end{tabular}

\begin{tabular}{|l|l|l|l|l|}
\hline Tyr & 2.343 & 9.068 & 10.181 & 0.977 \\
\hline 2.104 & 9.004 & 10.152 & 6.886 \\
\hline & & & \\
\hline
\end{tabular}




Aminoacid Carbox.acid Ammon.group Substituent
\begin{tabular}{|l|l|l|l|l|}
\hline Ala & 2.442 & 9.735 & & 4.778 \\
\hline & 2.449 & 9.783 & & 3.835 \\
\hline
\end{tabular}

Aminoacid Carbox.acid Ammon.group Substituent G.O.F.

\begin{tabular}{|l|l|l|l|l|}
\hline Arg & 2.285 & 9.264 & 12.758 & 3.807 \\
\hline 2.275 & 9.228 & 12.437 & 4.958 \\
\hline 2.264 & 9.339 & 13.402 & 2.250 \\
\hline
\end{tabular}

\begin{tabular}{|l|l|l|l|l|}
\hline His & 1.960 & 9.206 & 6.284 & 2.373 \\
\hline 1.921 & 9.146 & 6.232 & 1.577 \\
\hline & & & \\
\hline
\end{tabular}

\begin{tabular}{|l|c|c|c|c|}
\hline$l e$ & 2.439 & 9.758 & & 3.635 \\
\hline 2.426 & 9.679 & & 2.944 \\
\hline 2.431 & 9.728 & & 4.407 \\
\hline
\end{tabular}

\begin{tabular}{|l|l|l|l|l|}
\hline Asn & 2.346 & 8.787 & & 2.591 \\
\hline 2.223 & 8.892 & & 3.666 \\
\hline 2.273 & 8.816 & & 2.205 \\
\hline
\end{tabular}

\begin{tabular}{|l|l|l|l|l|}
\hline Leu & 2.437 & 9.793 & & 3.962 \\
\hline 2.426 & 9.702 & & 3.337 \\
\hline & & & \\
\hline
\end{tabular}

\begin{tabular}{|l|l|l|l|l|}
\hline Asp & 2.051 & 9.512 & 3.652 & 1.981 \\
\hline 2.040 & 9.649 & 3.699 & 3.236 \\
\hline & & & & \\
\hline
\end{tabular}

\begin{tabular}{|l|l|l|l|l|}
\hline Lys & 2.272 & 9.374 & 10.852 & 1.586 \\
\hline 2.313 & 9.400 & 10.842 & 5.097 \\
\hline & & & & \\
\hline
\end{tabular}

\begin{tabular}{|l|l|l|l|l|}
\hline Cys & 2.013 & 10.224 & 8.200 & 0.968 \\
\hline & 2.009 & 10.287 & 8.273 & 1.817 \\
\hline$(1.998)$ & $(10.376)$ & $(8.304)$ & 2.540 \\
\hline
\end{tabular}

\begin{tabular}{|l|c|c|c|c|}
\hline Tyr & 2.288 & 9.083 & 10.022 & 1.921 \\
\hline 2.376 & 9.105 & 10.019 & 2.745 \\
\hline$(2.457)$ & $(9.103)$ & $(9.974)$ & 5.551 \\
\hline
\end{tabular}

\begin{tabular}{|l|l|l|l|l|}
\hline Glu & 2.066 & 9.442 & 4.062 & 2.163 \\
\hline 2.258 & 9.510 & 4.145 & 5.357 \\
\hline 2.230 & 9.505 & 4.135 & 2.477 \\
\hline
\end{tabular}


Aminoacid Carbox,acid Ammon.group Substituent G.O.F.

\begin{tabular}{|l|l|l|l|l|}
\hline Ala & 2.713 & 10.059 & & 6.767 \\
\hline & 2.727 & 10.132 & & 6.066 \\
\hline & & & & \\
\hline
\end{tabular}

\begin{tabular}{|l|l|l|l|l|}
\hline Arg & 2.549 & 9.633 & 12.824 & 4.839 \\
\hline 2.558 & 9.636 & 12.846 & 5.282 \\
\hline & & & \\
\hline
\end{tabular}

\begin{tabular}{|l|l|l|l|l|}
\hline Asn & 2.452 & 9.094 & & 4.074 \\
\hline 2.471 & 9.172 & & 2.637 \\
\hline & & & \\
\hline
\end{tabular}

\begin{tabular}{|l|l|l|l|l|}
\hline Asp & 2.244 & 9.925 & 3.954 & 3.988 \\
\hline 2.273 & 9.856 & 3.938 & 4.691 \\
\hline & & & \\
\hline
\end{tabular}

\begin{tabular}{|l|l|l|l|l|}
\hline Cys & 2.269 & 10.372 & 8.433 & 3.918 \\
\hline & 2.277 & 10.280 & 8.356 & 4.184 \\
\hline 2.268 & 10.513 & 8.517 & 2.224 \\
\hline
\end{tabular}

\begin{tabular}{|l|l|l|l|l|}
\hline Glu & 2.493 & 9.766 & 4.437 & 4.142 \\
\hline 2.507 & 9.711 & 4.428 & 5.979 \\
\hline & & & \\
\hline
\end{tabular}

Aminoacid Carbox.acid Ammon.group Substituent G.O.F.

\begin{tabular}{|l|l|l|l|l|}
\hline His & 2.161 & 9.465 & 6.617 & 4.548 \\
\hline 2.140 & 9.435 & 6.581 & 4.339 \\
\hline & & & \\
\hline
\end{tabular}

\begin{tabular}{|l|l|l|l|l|}
\hline le & 2.718 & 10.055 & & 5.963 \\
\hline 2.711 & 10.030 & & 6.876 \\
\hline & & & \\
\hline
\end{tabular}

\begin{tabular}{|l|l|l|l|l|}
\hline Leu & 2.700 & 9.974 & & 5.505 \\
\hline 2.701 & 10.044 & & 5.724 \\
\hline & & & \\
\hline
\end{tabular}

\begin{tabular}{|l|l|l|l|l|}
\hline Lys & 2.603 & 9.711 & 11.043 & 6.122 \\
\hline 2.641 & 9.659 & 10.949 & 5.254 \\
\hline 2.612 & 9.738 & 11.045 & 3.155 \\
\hline
\end{tabular}

\begin{tabular}{|l|l|l|l|l|}
\hline Tyr & 2.590 & 9.380 & 10.210 & 2.558 \\
\hline & 2.641 & 9.346 & 10.151 & 2.120 \\
\hline & & & & \\
\hline
\end{tabular}




\section{K Sample Titration-Data Recording}

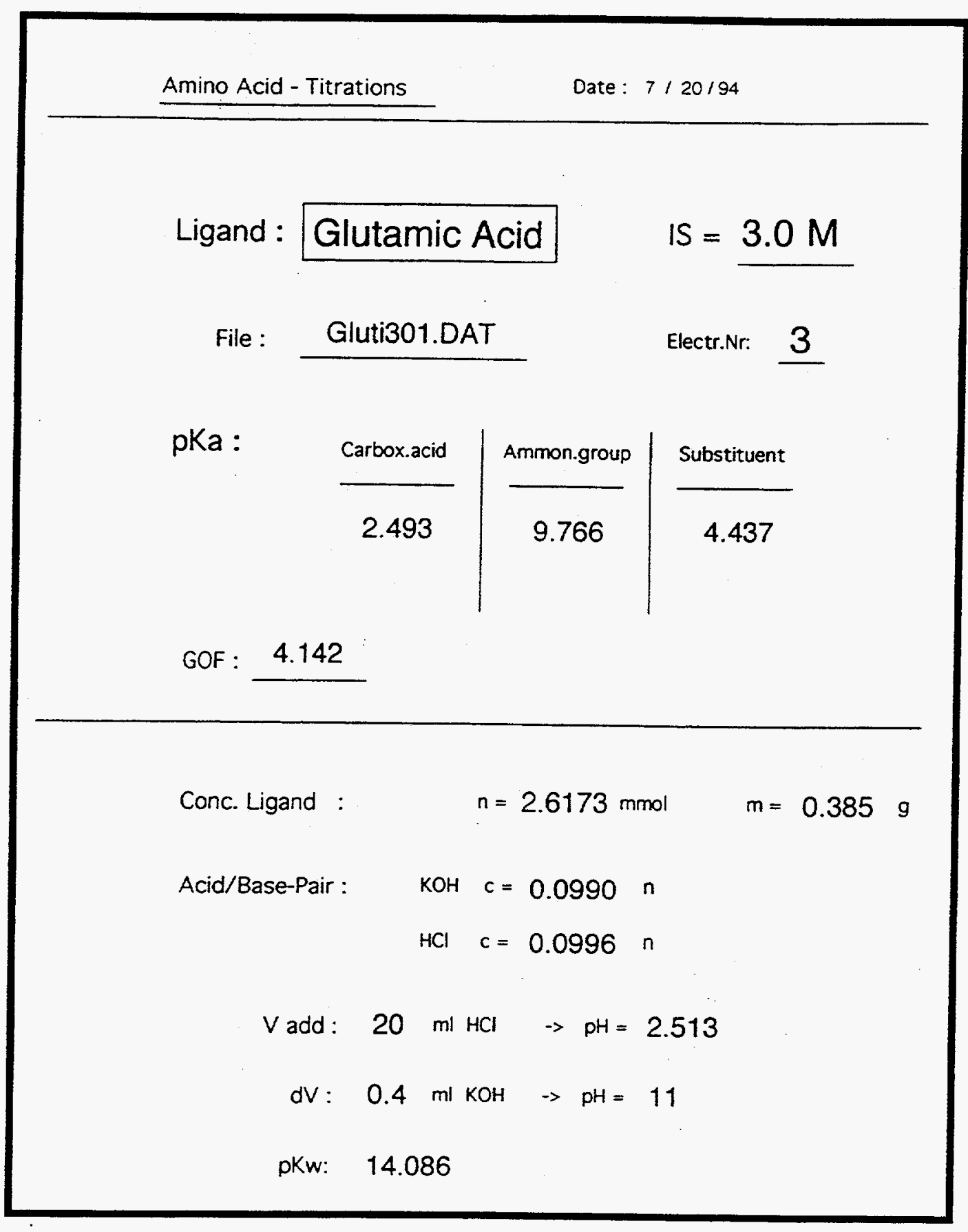

Figure 14: Example for fillout titration sheet for record keeping 
LEAST-SQUARES REFINEMENT SUMMARY

7-18-1994 Program: BETA90 (1-14-91) 9:29:21

\section{GLUTI301.INP}

pH-OBS CORRECTED WTTH INTERCEPT .0000 AND SLOPE 1.0000 $\mathrm{pK} w=14.00400$

NUMBER OF OBSERVATIONS IS 188 pH RANGE: 2.513 TO 11.018

TOTAL VOLUME OF TTTRANT ADDED: $74.800 \mathrm{~mL}$

TOTAL NO OF ACID/BASE SITES

NUMBER OF DEPROTONATED(SALT) SITES

NUMBER OF PROTONATED SITES

\section{2}

2

MILLIMOLES OF LIGAND 2.61600000

MOLARITY OF TITRANT $\quad-.099000$

VOLUME OF ADDED ACID $\quad .000000$

MOLARITY OF ADDED ACD $\quad .000000$

INITLAL SAMPLE VOLUME 270.000000

MIILDMOLES OF STOCK ACID 1.96100000

$\operatorname{Sigma}($ meter $)=.003$ Sigma $($ buret $)=.002$

INPUT DATA

\# BETA DAMPING DP(J) INDICES

$\begin{array}{lllllll}1 & 10.00 & 1 & .000 \mathrm{E}+00 & 1 & 1\end{array}$

$2 \quad 14.4011 \quad .000 \mathrm{E}+0012$

$\begin{array}{llllllll}3 & 16.60 & 1 & .000 \mathrm{E}+00 & 1 & 3\end{array}$

PARAMETERS AFTER FINAL REFINEMENT

$$
\text { OLD CHANGE NEW ERROR SHIFT/ERROR }
$$

$\begin{array}{llllll}1 & 9.7656 & .0000 & 9.7656 & .0017 & .0026\end{array}$

$\begin{array}{lllllll}2 & 14.2026 & .0000 & 14.2026 & .0024 & .0104\end{array}$

$\begin{array}{lllllll}3 & 16.6961 & -.0004 & 16.6957 & .0038 & .1014\end{array}$

Value of convergence function DELGOF $=\quad .0008$

FINAL AGREEMENT FACTORS:

SumlO-Cl IS $1.646 E+00$ Sum[W*(O-C)**2] IS $3.174 E+03$

Sum[Obs] IS $1.152 \mathrm{E}+03 \quad$ Sum[W*(Obs)**2] IS $9.580 \mathrm{E}+08$

$\operatorname{Sqr}\left[\operatorname{Sum}\left(W^{*}(\mathrm{O}-\mathrm{C})^{* *} 2\right) /(\mathrm{No}-\mathrm{Nv})\right]=4.1421$ (G.O.F.)

$R^{\prime}=.00143 \quad R w=.00182$

PROGRAM TERMINATED FOR REASON 3

CORRELATION MATRIX:

$\begin{array}{cccc}1 & 1.0000 & .6902 & .4368 \\ 2 & .0000 & 1.0000 & .4779 \\ 3 & .0000 & .0000 & 1.0000\end{array}$

Figure 15: Printout of summary file *.SUM containing all titration run information 


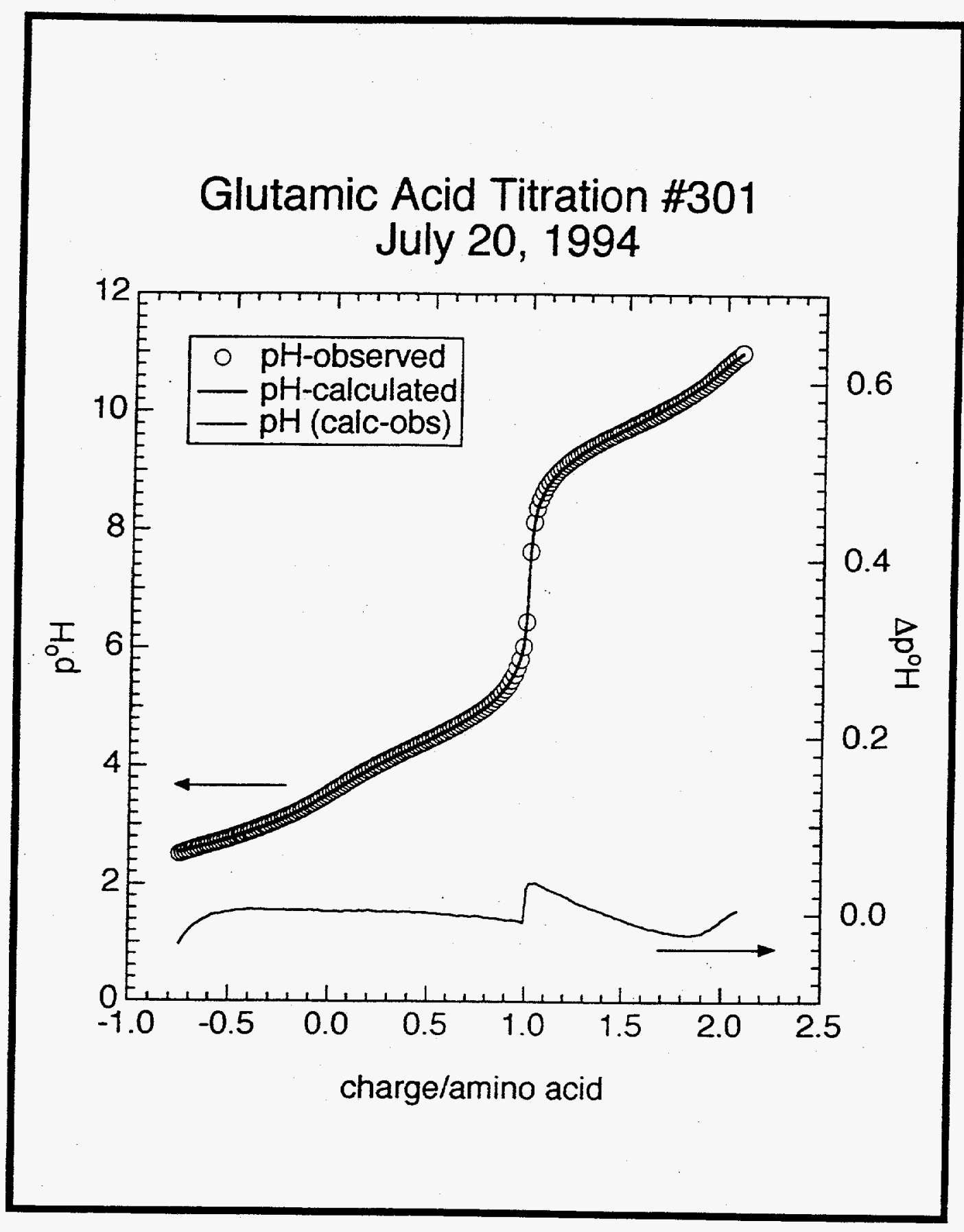

Figure 16: Plot of titration curves from PLOT.O\&C file 


\section{Nomenclature}

$\begin{array}{lcl}\mathrm{a} & - & \text { activity } \\ \mathrm{c} & \mathrm{mol} / 1 & \text { concentration } \\ \mathrm{E} & \mathrm{mV} & \text { measured hydrogen-ion activity } \\ \mathrm{E}^{\prime} & \mathrm{mV} & \text { electrode reference potential } \\ \mathrm{E}_{0} & \mathrm{mV} & \text { electrode intercept } \\ \mathrm{K}_{\mathrm{a}} & - & \text { hydrogen-ion dissociation constant } \\ \mathrm{m} & \mathrm{g} & \text { mass } \\ \mathrm{M} & \mathrm{g} / \mathrm{mol} & \text { molecular weight } \\ \mathrm{n} & - & \text { number of site } \\ \mathrm{P} & - & \text { protein } \\ \mathrm{R} & \mathrm{J} / \mathrm{mol} \cdot \mathrm{K} & \text { gas constant } \\ \mathrm{S} & \mathrm{mV} / \mathrm{pH} & \text { slope } \\ \mathrm{T} & \mathrm{K} & \text { temperature } \\ \mathrm{V} & \mathrm{mL} & \text { volume } \\ \mathrm{z} & - & \text { charge per amino acid or protein } \\ & & \\ \Delta & & \\ \gamma & - & \text { difference } \\ & & \text { activity coefficient } \\ & & \end{array}$

\section{Subscript:}

i

net

prot

Superscript:

o species $\mathrm{i}$

net charge

protein 


\section{References}

1. Shih, Y.-C., J.M. Prausnitz, and H.W. Blanch, Some Characteristics of Protein Precipitation by Salt. Biotech. Bioeng., 1992. 40: p. 1155.

2. Vlachy, V., H.W. Blanch, and J.M. Prausnitz, Liquid-Liquid Phase Separation in Aqueous Solutions of Globular Proteins. AIChE J., 1993. 39: p. 215.

3. Coen, C.J., H.W. Blanch, and J.M. Prausnitz, Protein in Aqueous Electrolyte Solutions: Measurement of Salting-Out Phase Equilibria and Comments on Protein Intermolecular Potentials. 1992, University of California, Berkeley.

4. Martell, A.E. and R.M. Smith, Critical Stability Constants. Vol. Volume 1: Amino Acids. 1974, New York: Plenum Press.

5. Bashford, D. and M. Karplus, $p K a$ 's of Ionizable Groups in Proteins: Atomic Detail from a Continuum Electrostatic Model. Biochemistry, 90. 29(44): p. 10219.

6. Tanford, C., Physical Chemistry of Macromolecules. 1961, New York: John Wiley \& Sons.

7. Harris, D.C., Quantitative Chemical Analysis. 3rd ed. 1991, New York: W. H. Freeman and Company.

8. Bates, R.G., Determination of pH Theory and Practice. 2nd ed. 1973, New York: John Wiley \& Sons.

9. Zemaitis, J.F., et al., Handbook of Aqueous Electrolyte Thermodynamics. 1986, New York: AIChE, DIPPR.

10. Franczyk, T.S., Potentiometric Titrator Software Guide. 1990, University of California, Berkeley.

11. Tinoco, S., Wang, Physical Chemistry. 2nd ed. 1985, Englewood Cliffs, New Jersey: Prentice-Hall, Inc.

12. Orion, ROSS pH Electrode Instruction Manual. 1990.

13. Tanford, C. and M.L. Wagner, Hydrogen Ion Equilibria of Lysozyme. JACS, 1954. 76: p. 3332.

14. Boyer, P.D., The Enzymes. Vol. Volume 7. 1972, New York: Academic Press.

15. Fersht, A., Enzyme Structure and Mechanism. 2 ed. 1985, New York: W. H. Freeman and Company.

16. Keithley, User Guide for Data Acquisition Boards. 1993. 